Supplement of Atmos. Chem. Phys., 21, 11467-11487, 2021

https://doi.org/10.5194/acp-21-11467-2021-supplement

(C) Author(s) 2021. CC BY 4.0 License.

(c) (1)

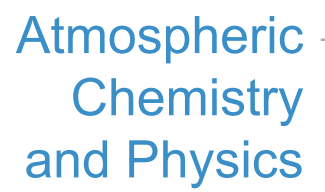

Supplement of

\title{
Using GECKO-A to derive mechanistic understanding of secondary organic aerosol formation from the ubiquitous but understudied camphene
}

Isaac Kwadjo Afreh et al.

Correspondence to: Kelley Claire Barsanti (kbarsanti@engr.ucr.edu)

The copyright of individual parts of the supplement might differ from the article licence. 


\section{List of Tables}

Table S1: SOA data compiled from published chamber studies for photooxidation and ozonolysis of $\alpha$-pinene and limonene.

Table S2: Normalized emission factor (EF) for model surrogates representing top five monoterpenes (by EF) from black spruce, Douglas fir, and lodgepole pine (Hatch et al., 2015, 2017). In Assignment 1, $\alpha$-pinene is used to represent all monoterpenes except limonene. In Assignment 2, camphene is represented as $50 \%$ \%-pinene and $50 \%$ limonene. EFs of assignments 1 and 2 for lodgepole pine are the same, because camphene is not one of the top five monoterpenes by EF. ... 6 Table S3: Two-product SOA yield parameters for $\alpha$-pinene and limonene based on Griffin et al. (1999).

Table S4: Volatility basis set (VBS) parameters (low NO , dry) based on Pathak et al. (2007b) (for $\alpha$-pinene) and Zhang et al. (2006) (for limonene).

List of Figures

Figure S1: Initial oxidation pathways of $\alpha$-pinene with $\mathrm{O}_{3}$ as represented in GECKO-A (inorganic products are not shown).

Figure S2: Initial oxidation pathways of limonene with $\mathrm{O}_{3}$ as represented in GECKO-A (inorganic products are not shown).

Figure S3: Initial oxidation pathways of camphene with $\mathrm{O}_{3}$ as represented in GECKO-A (inorganic products are not shown).

Figure S4: Initial oxidation pathways of $\alpha$-pinene with $\mathrm{NO}_{3}$ as represented in GECKO-A (inorganic products are not shown).

Figure S5: Initial oxidation pathways of limonene with $\mathrm{NO}_{3}$ as represented in GECKO-A (inorganic products are not shown).

Figure S6: Initial oxidation pathways of camphene with $\mathrm{NO}_{3}$ as represented in GECKO-A (inorganic products are not shown).

Figure S7: Percentage of precursor consumed by $\mathrm{OH}$ (black), $\mathrm{O}_{3}$ (red), and $\mathrm{NO}_{3}$ (blue) as a function of fraction of precursor reacted for $\alpha$-pinene and limonene under photooxidation and ozonolysis (for lower initial precursor mixing ratio of 50 ppb)......

Figure S8: The mixing ratios of $\mathrm{HO}_{2}, \mathrm{OH}, \mathrm{O}_{3}, \mathrm{NO}, \mathrm{NO}_{2}$, and $\mathrm{NO}_{3}$ as a function of time for $\alpha$-pinene (blue line) and limonene (red line) (with the low initial hydrocarbon (LHC) mixing ratio of 50 ppb) during photooxidation (P) and dark ozonolysis (DO) simulations.

Figure S9: Number of functional groups associated with gas- and particle-phase species as a function of carbon number. Results are shown for camphene, $\alpha$-pinene, and limonene after 12 hours of oxidation under photooxidation (P) and dark ozonolysis (DO) with lower hydrocarbon (LHC) mixing ratio of 50 ppb. The markers are sized by the ratio of their mixing ratio (in ppbC) to the initial mixing ratio of the precursor (in ppbC). The colors of the markers are scaled by volatility (represented by saturation concentration, $\left.\mathrm{C}^{*}\right)$. 
Figure S10: Top 10 gas-phase products from limonene photooxidation at the end of the low hydrocarbon (P_LHC) simulation.

Figure S11: Top 10 particle-phase products from limonene photooxidation at the end of the low hydrocarbon (P_LHC) simulation.

Figure S12: Top 10 gas-phase products from limonene dark ozonolysis at the end of the low hydrocarbon (DO_LHC) simulation.

Figure S13: Top 10 particle-phase products from limonene dark ozonolysis at the end of the low hydrocarbon (DO_LHC) simulation.

Figure S14: Simulated SOA mass as a function of time for $\alpha$-pinene and limonene during photooxidation and dark ozonolysis with low hydrocarbon mixing ratio $(50 \mathrm{ppb})$.

Figure S15: Simulated average $\mathrm{O} / \mathrm{C}$ as a function of time for $\alpha$-pinene and limonene during photooxidation and dark ozonolysis with low hydrocarbon mixing ratio $(50 \mathrm{ppb})$.

Figure S 16: Concentration of top 10 gas- and particle-phase products as a function of time for $\alpha$-pinene and limonene during photooxidation with low hydrocarbon mixing ratio (50 ppb).

Figure S 17: Concentration of top 10 gas- and particle-phase products as a function of time for $\alpha$-pinene and limonene during dark ozonolysis with low hydrocarbon mixing ratio (50 ppb).

Figure S18: Simulated SOA yield as a function of time (a and b) and carbon budget (c to f) for $\alpha$-pinene and limonene during photooxidation (a, c, e) and dark ozonolysis $(b, d, f)$. The SOA yield curve for $\alpha$-pinene is represented by a blue line; limonene is represented by a red line. For the carbon budget plots, the mixing ratios of the precursor (black line), particle-phase organics (magenta line), gas-phase organics (green line), and $\mathrm{CO}+\mathrm{CO}_{2}$ (blue line) are expressed as carbon atom ratios (in ppbC)/initial precursor (in ppbC). The results shown are for the high hydrocarbon mixing ratio (150 ppb) simulations.

Figure S19: Percentage of precursor consumed by $\mathrm{OH}$ (black), $\mathrm{O}_{3}$ (red), and $\mathrm{NO}_{3}$ (blue) as a function of fraction of precursor reacted for $\alpha$-pinene and limonene under photooxidation and ozonolysis (for higher initial precursor concentration of $150 \mathrm{ppb})$.

Figure S20: Mixing ratios of $\mathrm{HO}_{2}, \mathrm{OH}, \mathrm{O}_{3}, \mathrm{NO}, \mathrm{NO}_{2}$, and $\mathrm{NO}_{3}$ as function of time for limonene (red line), camphene (black line), and $\alpha$-pinene (blue line) during the photooxidation and ozonolysis (with higher initial hydrocarbon mixing ratio of $150 \mathrm{ppb})$..

Figure S21: Number of functional groups associated with gas- and particle-phase species as a function of carbon number. Results are shown for camphene, $\alpha$-pinene, and limonene after 12 hours of oxidation under photooxidation (P) and dark ozonolysis (DO) with higher hydrocarbon (LHC) mixing ratio of 150 ppb. The markers are sized by the ratio of their mixing ratio (in ppbC) to the initial mixing ratio of the precursor (in ppbC). The colors of the markers are scaled by volatility (represented by saturation concentration, $\mathrm{C} *$ ).....

Figure S22: Top 10 gas-phase products from $\alpha$-pinene photooxidation at the end of the high hydrocarbon $\left(\mathbf{P} \_H H C\right)$ simulations.

Figure S23: Top 10 particle-phase products from $\alpha$-pinene photooxidation at the end of the high hydrocarbon (P_HHC) simulations.

Figure S24: Top 10 gas-phase products from $\alpha$-pinene dark ozonolysis at the end of the high hydrocarbon (DO_HHC) simulations. 
Figure S25: Top 10 particle-phase products from $\alpha$-pinene dark ozonolysis at the end of the high hydrocarbon (DO_HHC) simulations.

Figure S26: Top 10 gas-phase products from limonene photooxidation at the end of the high hydrocarbon (P_HHC)....23 Figure S27: Top 10 particle-phase products from limonene photooxidation at the end of the high hydrocarbon (P_HHC).

Figure S28: Top 10 gas-phase products from limonene dark ozonolysis at the end of the high hydrocarbon (DO_HHC). 24 Figure S29: Top 10 particle-phase products from limonene dark ozonolysis at the end of the high hydrocarbon (DO_HHC).

Figure S30: Percentage of precursor reacted by $\mathrm{OH}$ (black), $\mathrm{O}_{3}$ (red), and $\mathrm{NO}_{3}$ (blue) as a function of fraction of precursor reacted for $\alpha$-pinene, camphene, and limonene during controlled reactivity $(\mathrm{CR})$ simulations. .25

Figure S31: Top 10 gas-phase products from camphene at the end of the controlled reactivity simulation. .25

Figure S32: Top 10 particle-phase products from camphene at the end of the controlled reactivity simulation. 26 Figure S33: (a) Simulated SOA yield as a function of atmospheric aging time for: camphene (black line), $50 \% \alpha$-pinene + $50 \%$ limonene (magenta line), $\alpha$-pinene with camphene rate constants (blue line), limonene with camphene rate constants (red line), and $50 \% \alpha$-pinene $+50 \%$ limonene where the rate constants of $\alpha$-pinene and limonene were replaced with the rate constants of camphene (green line); and (b) mass percentage of particle-phase compounds binned in four volatility categories at the end of the controlled reactivity simulations for: camphene, $50 \% \alpha$-pinene $+50 \%$ limonene, $\alpha$-pinene with camphene rate constants, limonene with camphene rate constants, and $50 \% \alpha$-pinene $+50 \%$ limonene where the rate constants of $\alpha$-pinene and limonene were replaced with the rate constants of camphene. 
Table S1: SOA data compiled from published chamber studies for photooxidation and ozonolysis of $\alpha$-pinene and limonene.

\begin{tabular}{|c|c|c|c|c|c|c|c|c|}
\hline Condition & $\begin{array}{c}\mathrm{T} \\
(\mathrm{K})\end{array}$ & $\begin{array}{l}{\left[\mathrm{O}_{3}\right]_{\mathrm{o}}} \\
(\mathrm{ppb})\end{array}$ & $\begin{array}{l}\mathrm{NO}_{\mathrm{x}} \\
(\mathrm{ppb})\end{array}$ & $\begin{array}{l}{[\mathrm{HC}]_{\mathrm{o}}} \\
(\mathrm{ppb})\end{array}$ & $\begin{array}{c}\Delta \mathrm{HC} \\
\left(\mu \mathrm{g} \mathrm{m}^{-3}\right)\end{array}$ & $\begin{array}{l}\text { SOA mass } \\
\left(\mu \mathrm{g} \mathrm{m}^{-3}\right)\end{array}$ & $\begin{array}{l}\text { SOA } \\
\text { yield }\end{array}$ & Reference \\
\hline$\alpha$-Pinene photooxidation & $312-306$ & & 230 & 150 & 804.6 & 44.0 & 0.06 & Kim and Paulson (2013) \\
\hline$\alpha$-Pinene photooxidation & $310-312-306$ & & 110 & 152 & 788.8 & 103.0 & 0.14 & Kim and Paulson (2013) \\
\hline$\alpha$-Pinene photooxidation & $306-309$ & & 50 & 142 & 743.9 & 107.0 & 0.16 & Kim and Paulson (2013) \\
\hline$\alpha$-Pinene photooxidation & $312-319-315$ & & 47 & 153 & 683.0 & 118.0 & 0.17 & Kim and Paulson (2013) \\
\hline$\alpha$-Pinene photooxidation & 300 & & & 51 & 260.0 & 46.0 & 0.18 & Mcvay et al. (2016) \\
\hline$\alpha$-Pinene photooxidation & 300 & & & 56 & 280.0 & 65.0 & 0.23 & Mcvay et al. (2016) \\
\hline$\alpha$-Pinene photooxidation & 300 & & & 53 & 240.0 & 52.0 & 0.22 & Mcvay et al. (2016) \\
\hline$\alpha$-Pinene photooxidation & 298 & & & 51 & 268.0 & 72.0 & 0.27 & Mcvay et al. (2016) \\
\hline$\alpha$-Pinene photooxidation & 297 & & & 53 & 205.0 & 35.0 & 0.17 & Mcvay et al. (2016) \\
\hline$\alpha$-Pinene photooxidation & 297 & & & 49 & 195.0 & 47.0 & 0.24 & Mcvay et al. (2016) \\
\hline$\alpha$-Pinene photooxidation & 293 & & & & 616.6 & 199.0 & 0.32 & Lee et al. (2006b) \\
\hline$\alpha$-Pinene photooxidation & 298 & & 0 & & 76.8 & 29.3 & 0.38 & $\mathrm{Ng}$ et al. (2007) \\
\hline$\alpha$-Pinene photooxidation & 298 & & 1 & & 264.2 & 121.3 & 0.46 & Ng et al. (2007) \\
\hline$\alpha$-Pinene photooxidation & 296 & & 198 & & 73.4 & 15.6 & 0.21 & $\mathrm{Ng}$ et al. (2007) \\
\hline$\alpha$-Pinene photooxidation & 299 & & 938 & & 69.8 & 4.5 & 0.06 & $\mathrm{Ng}$ et al. (2007) \\
\hline$\alpha$-Pinene photooxidation & 298 & & 968 & & 259.2 & 40.8 & 0.16 & Ng et al. (2007) \\
\hline$\alpha$-Pinene photooxidation & & & 0 & & 259.9 & 63.9 & 0.25 & Chhabra et al. (2011) \\
\hline$\alpha$-Pinene photooxidation & & & 400 & & 265.6 & 53.7 & 0.20 & Chhabra et al. (2011) \\
\hline Limonene photooxidation & $310-305$ & & 300 & 208 & 1110.4 & $96-287$ & 0.35 & Kim and Paulson (2013) \\
\hline Limonene photooxidation & $309-313$ & & 98 & 140 & 735.5 & $34-195$ & 0.35 & Kim and Paulson (2013) \\
\hline Limonene photooxidation & $297-299$ & & 120 & 157 & 801.0 & $32-214$ & 0.37 & Kim and Paulson (2013) \\
\hline Limonene photooxidation & $311-315$ & & 41 & 130 & 680.0 & $11-219$ & 0.43 & Kim and Paulson (2013) \\
\hline Limonene photooxidation & $308-312-307$ & & 39 & 130 & 690.6 & $14-275$ & 0.47 & Kim and Paulson (2013) \\
\hline Limonene photooxidation & 313.4 & & 105 & & 109.0 & 9.5 & 0.09 & Griffin et al. (1999) \\
\hline Limonene photooxidation & 313.4 & & 80.2 & & 186.2 & 49.6 & 0.27 & Griffin et al. (1999) \\
\hline Limonene photooxidation & 309.4 & & 139 & & 265.2 & 79.1 & 0.30 & Griffin et al. (1999) \\
\hline Limonene photooxidation & 309.4 & & 140 & & 348.8 & 120.2 & 0.34 & Griffin et al. (1999) \\
\hline Limonene photooxidation & 294 & & & & 676.5 & 394.0 & 0.58 & Lee et al. (2006b) \\
\hline$\alpha$-Pinene ozonolysis & $299-300$ & 500 & & 143 & 592.2 & $28-230$ & 0.46 & Kim and Paulson (2013) \\
\hline$\alpha$-Pinene ozonolysis & $296-299$ & 500 & & 150 & 724.3 & $39-271$ & 0.44 & Kim and Paulson (2013) \\
\hline$\alpha$-Pinene ozonolysis & $296-301$ & 500 & & 170 & 866.2 & $37-271$ & 0.40 & Kim and Paulson (2013) \\
\hline$\alpha$-Pinene ozonolysis & $296-295$ & 500 & & 160 & 897.5 & 71-349 & 0.45 & Kim and Paulson (2013) \\
\hline$\alpha$-Pinene ozonolysis & $291-293$ & 500 & & 126 & 669.8 & $34-215$ & 0.39 & Kim and Paulson (2013) \\
\hline$\alpha$-Pinene ozonolysis & & 200 & & 49.5 & 282.0 & 42.3 & 0.15 & Kourtchev et al. (2014) \\
\hline$\alpha$-Pinene ozonolysis & & 200 & & 50.5 & 312.5 & 50.0 & 0.16 & Kourtchev et al. (2014) \\
\hline
\end{tabular}


$\alpha$-Pinene ozonolysis

$\alpha$-Pinene ozonolysis

$\alpha$-Pinene ozonolysis

$\alpha$-Pinene ozonolysis

$\alpha$-Pinene ozonolysis

$\alpha$-Pinene ozonolysis

$\alpha$-Pinene ozonolysis

$\alpha$-Pinene ozonolysis

$\alpha$-Pinene ozonolysis

$\alpha$-Pinene ozonolysis

$\alpha$-Pinene ozonolysis

$\alpha$-Pinene ozonolysis

$\alpha$-Pinene ozonolysis

$\alpha$-Pinene ozonolysis

$\alpha$-Pinene ozonolysis

$\alpha$-Pinene ozonolysis

$\alpha$-Pinene ozonolysis

$\alpha$-Pinene ozonolysis

$\alpha$-Pinene ozonolysis

$\alpha$-Pinene ozonolysis

$\alpha$-Pinene ozonolysis

$\alpha$-Pinene ozonolysis

$\alpha$-Pinene ozonolysis

$\alpha$-Pinene ozonolysis

$\alpha$-Pinene ozonolysis

$\alpha$-Pinene ozonolysis

Limonene ozonolysis

Limonene ozonolysis

Limonene ozonolysis

Limonene ozonolysis

Limonene ozonolysis

Limonene ozonolysis

Limonene ozonolysis

Limonene ozonolysis

Limonene ozonolysis
200

$298 \quad 100$

$298 \quad 100$

$298 \quad 100$

$298 \quad 500$

$298 \quad 500$

$298 \quad 500$

309.9

309.9

303.3

303.3

308

308

308

237

308

269

306

74

293

$298.15 \pm 12 \quad 300$

$298.15 \pm 13 \quad 300$

$298.15 \pm 14 \quad 300$

$298.15 \pm 15 \quad 300$

$298.15 \pm 16 \quad 300$

$298.15 \pm 17 \quad 300$

$298.15 \pm 18 \quad 300$

$298.15 \pm 19 \quad 300$

0

298-300 500

293-295 500

294-296 500

$\begin{array}{lll}295-296 & 69.7 \quad 33.7\end{array}$

295-296 $71 \quad 35.2$

295-297 $72.1 \quad 58.9$

296-297 $70.3 \quad 62.4$

296-297

$1.1 \quad 67.1$

295-296

$0.9 \quad 68.2$

$55.2 \quad 349.4$

$290.2 \pm 23.2 \quad 278.1$

$280.5 \pm 22.4 \quad 267.0$

$238.7 \pm 19.1 \quad 222.5$

$274 \pm 21.9 \quad 278.1$

$264 \pm 21.2 \quad 261.4$

$236.1 \pm 18.9$

239.2

89.3

97.3

169.4

248.7

306.7

349.8

59.2

67.2

107.1

306.7

350.3

244.3

1052.2

126.8

11.7

15.6

78.9

506.5

506.5

36.7

5.0

278.1

167

198

150

154

150

158

153

155

925.8

257.0

269.0

220.0

228.0

144.0

159

138.0
55.9

0.16

$62.0 \pm 1.2 \quad 0.23$

Kourtchev et al. (2014)

$63.0 \pm 0.8$

$50.6 \pm 1.6 \quad 0.23 \quad$ Nah et al. (2016)

$87.3 \pm 0.3 \quad 0.32 \quad$ Nah et al. (2016)

$75.7 \pm 0.6 \quad 0.29 \quad$ Nah et al. (2016)

$66.3 \pm 1.9 \quad 0.28 \quad$ Nah et al. (2016)

$7.4 \quad 0.08$

Griffin et al. (1999)

$8.5 \quad 0.09 \quad$ Griffin et al. (1999)

$30.3 \quad 0.18 \quad$ Griffin et al. (1999)

$46.0 \quad 0.18 \quad$ Griffin et al. (1999)

52.3

0.17 Griffin et al. (1999)

$65.1 \quad 0.19 \quad$ Griffin et al. (1999)

$54.2 \quad 0.18 \quad$ Yu et al. (1999)

$65.1 \quad 0.19 \quad$ Yu et al. (1999)

$38.8 \quad 0.16 \quad$ Yu et al. (1999)

$417.0 \quad 0.41 \quad$ Lee et al. (2006a)

35.6

0.28

Chen et al. (2011)

1.2

0.10

Chen et al. (2011)

1.9

0.12

Chen et al. (2011)

15.4

0.20

Chen et al. (2011)

95.2

0.19 Chen et al. (2011)

138.0

0.27 Chen et al. (2011)

$7.0 \quad 0.19$ Chen et al. (2011)

$0.5 \quad 0.10 \quad$ Chen et al. (2011)

62.0

0.22

Chhabra et al. (2011)

579.0

0.78 Kim and Paulson (2013)

$1116.3 \quad 614.0 \quad 0.72 \quad$ Kim and Paulson (2013)

$842.8 \quad 454.0 \quad 0.72 \quad$ Kim and Paulson (2013)

135.7

0.49 Chen et al. (2017)

$137.2 \quad 0.51 \quad$ Chen et al. (2017)

156.5 0.73 Chen et al. (2017)

157.3

0.72 Chen et al. (2017)

30.3

0.27 Chen et al. (2017)

31.8

0.30 Chen et al. (2017) 
Table S2: Normalized emission factor (EF) for model surrogates representing top five monoterpenes (by EF) from black spruce, Douglas fir, and lodgepole pine (Hatch et al., 2015, 2017). In Assignment 1, $\alpha$-pinene is used to represent all monoterpenes except limonene. In Assignment 2, camphene is represented as 50 \% $\alpha$-pinene and $50 \%$ limonene. EFs of assignments 1 and 2 for lodgepole pine are the same, because camphene is not one of the top five monoterpenes by EF.

\begin{tabular}{ccccccc}
\hline & \multicolumn{3}{c}{ Black Spruce } & \multicolumn{2}{c}{ Douglas Fir } & \multicolumn{2}{c}{ Lodgepole Pine } \\
\hline & $\mathrm{EF}_{\text {apin }}$ & $\mathrm{EF}_{\text {lim }}$ & $\mathrm{EF}_{\text {apin }}$ & $\mathrm{EF}_{\text {lim }}$ & $\mathrm{EF}_{\text {apin }}$ & $\mathrm{EF}_{\text {lim }}$ \\
\hline Assignment 1 & 0.81 & 0.19 & 0.8 & 0.2 & 0.86 & 0.14 \\
Assignment 2 & 0.62 & 0.38 & 0.6 & 0.4 & 0.86 & 0.14 \\
\hline
\end{tabular}

Table S3: Two-product SOA yield parameters for $\alpha$-pinene and limonene based on Griffin et al. (1999).

\begin{tabular}{ccccc}
\hline \multicolumn{5}{c}{ 2-product } \\
\hline & $\alpha_{1}$ & $\alpha_{2}$ & $\mathrm{C}^{*}{ }_{1}$ & $\mathrm{C}^{*}{ }_{2}$ \\
\hline$\alpha$-pinene & 0.038 & 0.326 & 5.8 & 250.0 \\
limonene & 0.239 & 0.363 & 18.2 & 188.7 \\
\hline
\end{tabular}

Table S4: Volatility basis set (VBS) parameters (low NOx, dry) based on Pathak et al. (2007b) (for a-pinene) and Zhang et al. (2006) (for limonene).

\begin{tabular}{cccccc}
\hline \multicolumn{7}{c}{ VBS $($ low NO $)$} \\
\hline $\mathbf{C}^{*}$ & 0 & 1 & 10 & 100 & 1000 \\
\hline$\alpha$-pinene & - & 0.07 & 0.038 & 0.179 & 0.3 \\
limonene & 0.03 & 0.29 & 0.31 & 0.3 & 0.6 \\
\hline
\end{tabular}




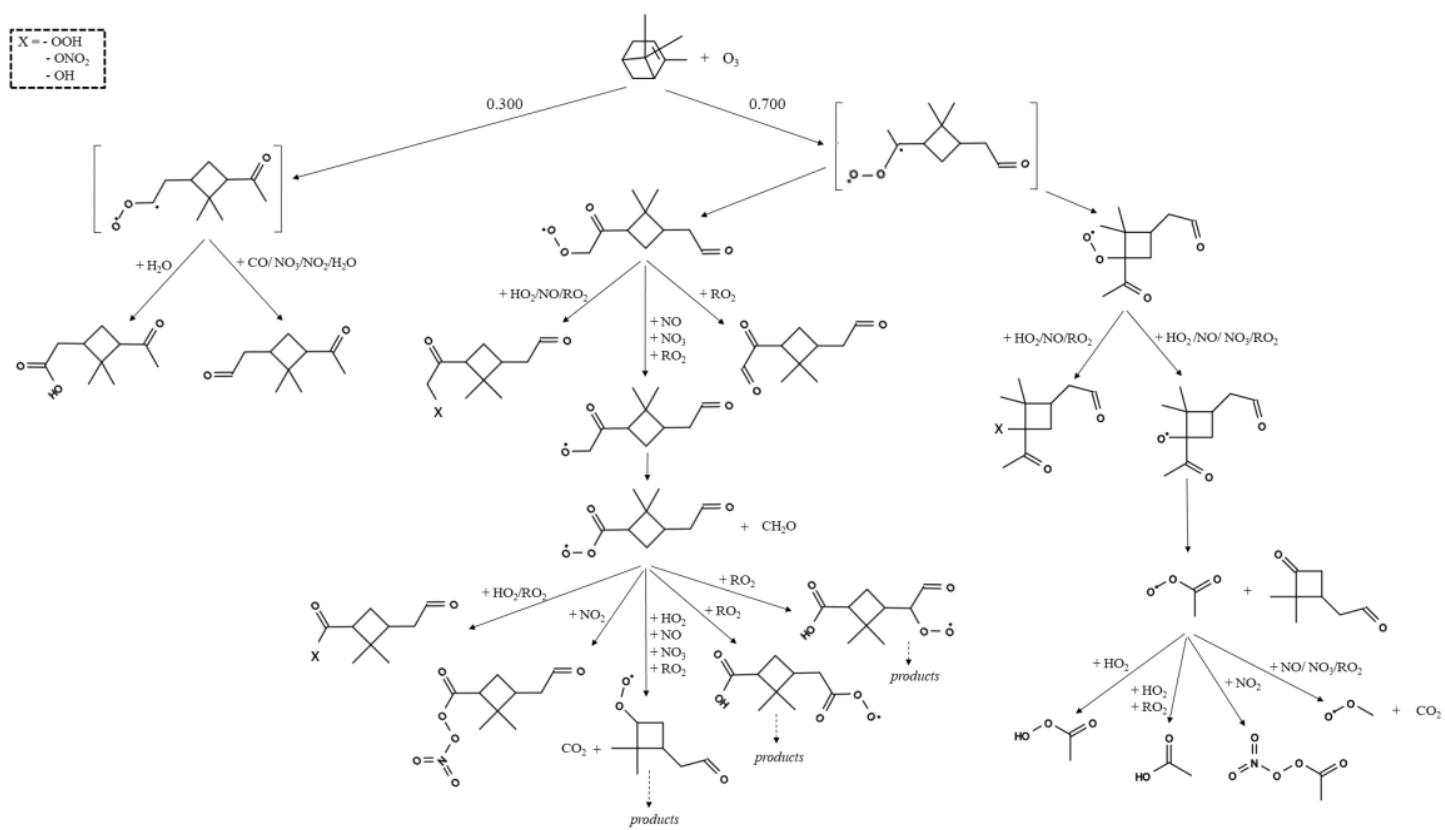

Figure S1: Initial oxidation pathways of $\alpha$-pinene with $\mathrm{O}_{3}$ as represented in GECKO-A (inorganic products are not shown).

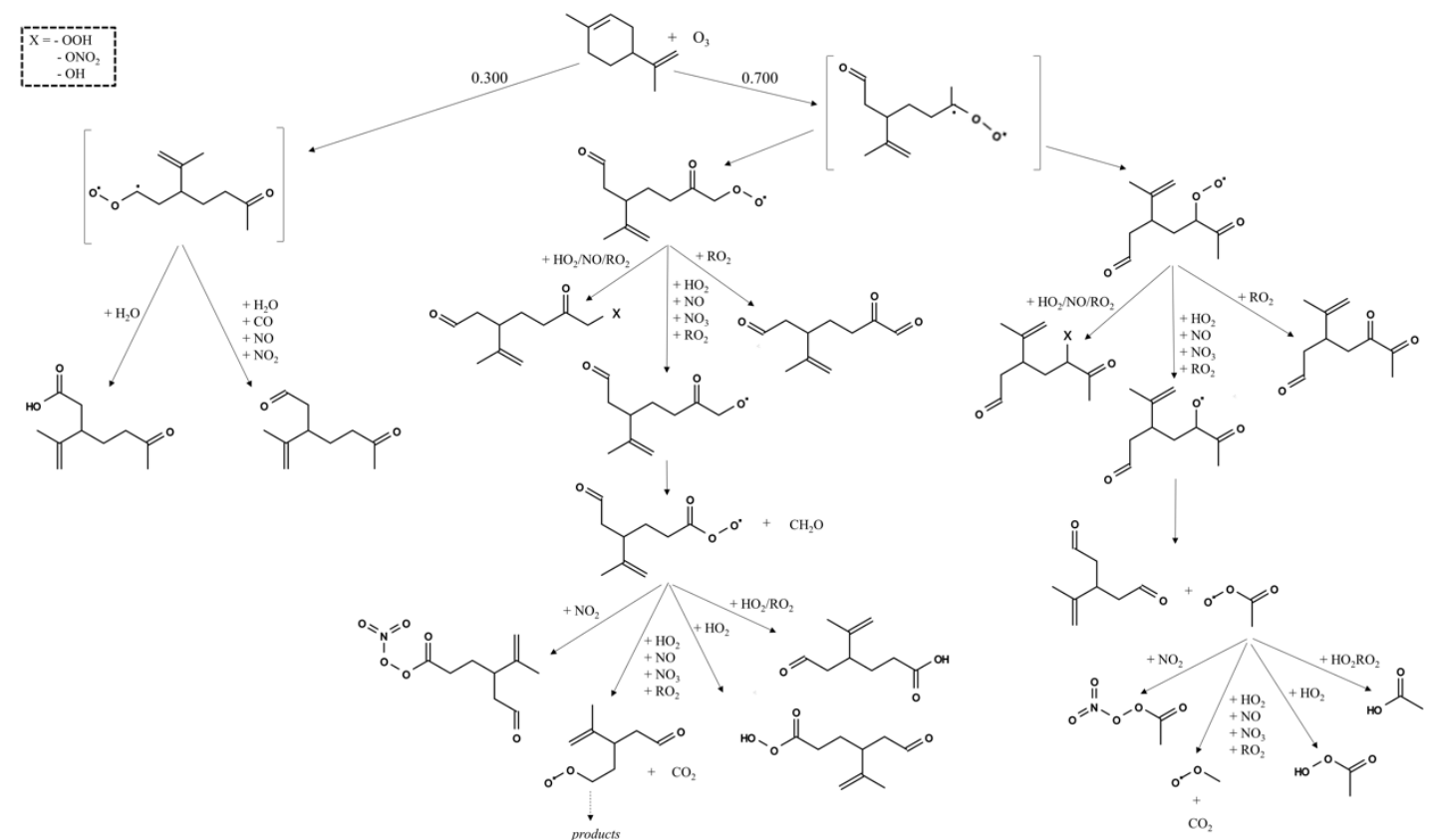

Figure S2: Initial oxidation pathways of limonene with $\mathrm{O}_{3}$ as represented in GECKO-A (inorganic products are not shown). 


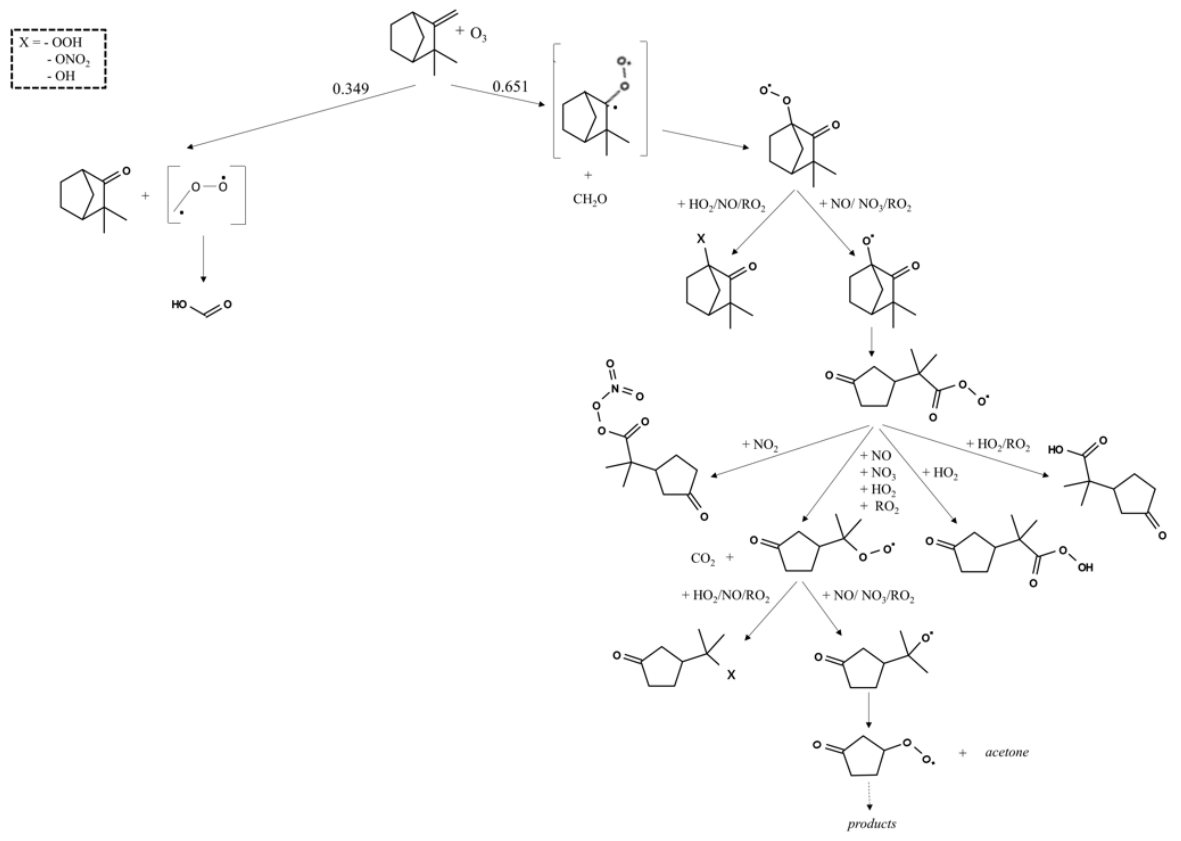

Figure S3: Initial oxidation pathways of camphene with $\mathrm{O}_{3}$ as represented in GECKO-A (inorganic products are not shown).

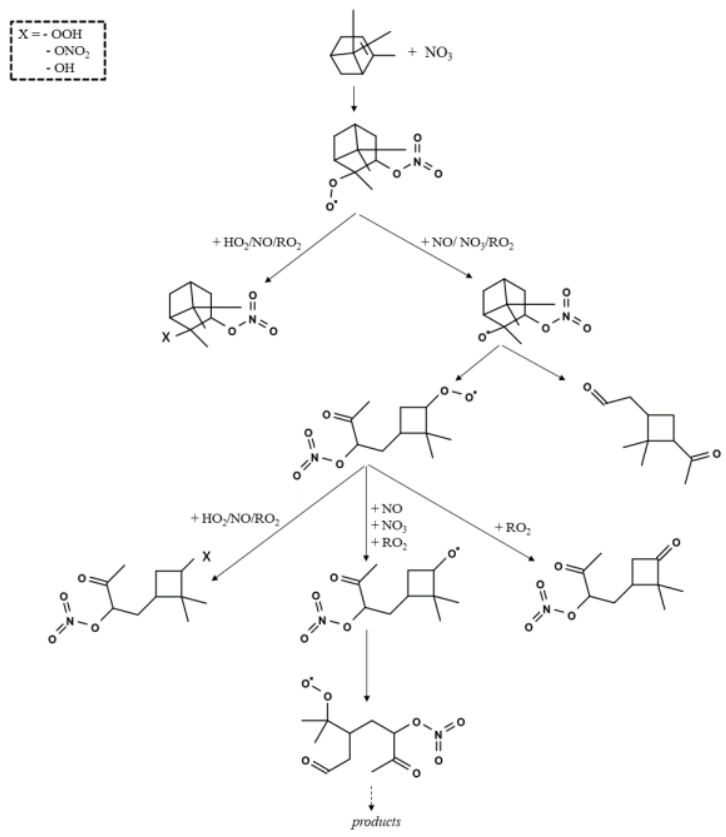

Figure S4: Initial oxidation pathways of $\alpha$-pinene with $\mathrm{NO}_{3}$ as represented in GECKO-A (inorganic products are not shown). 


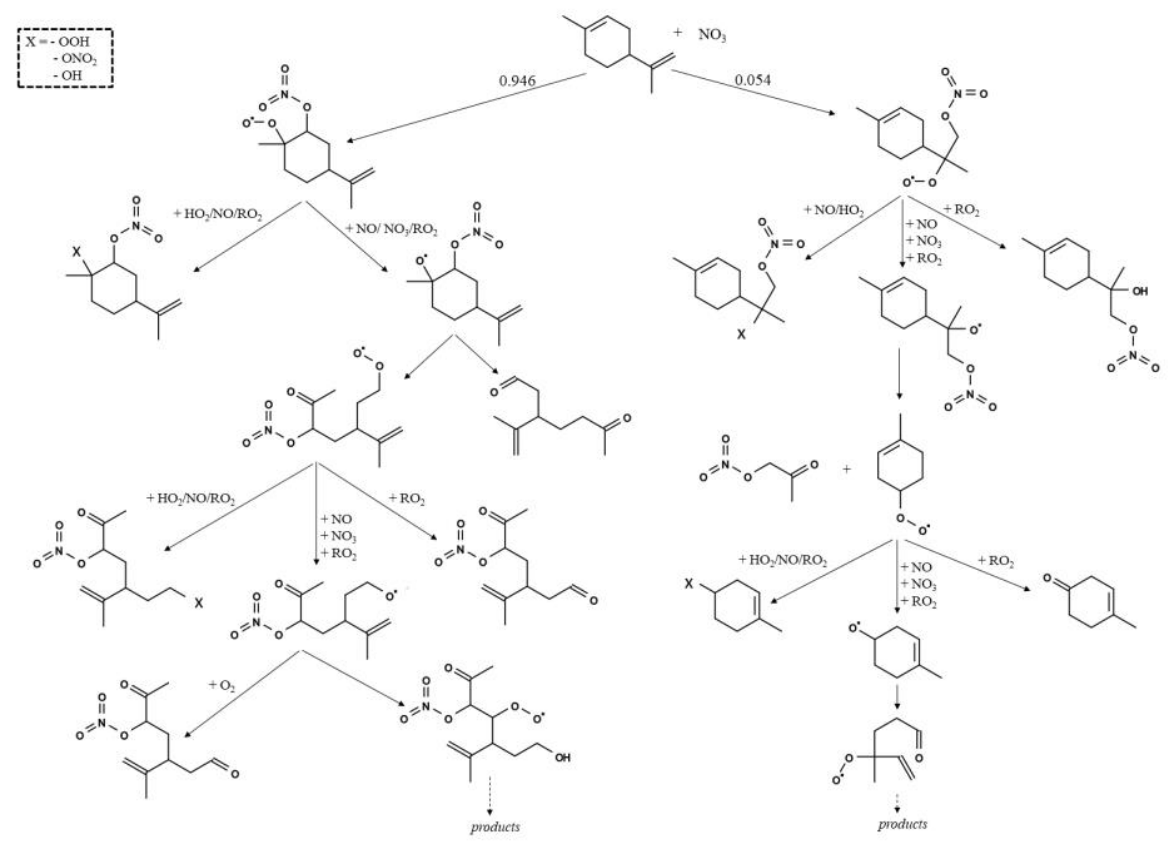

Figure S5: Initial oxidation pathways of limonene with $\mathrm{NO}_{3}$ as represented in GECKO-A (inorganic products are not shown).

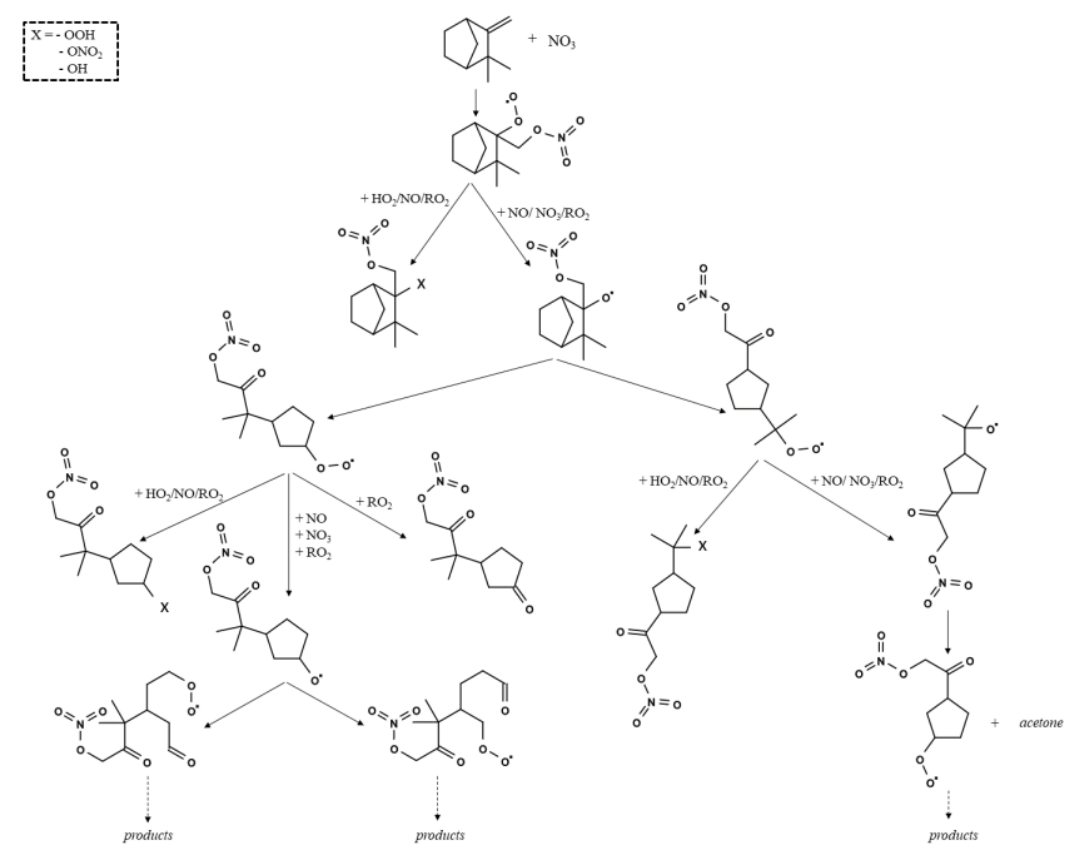

Figure S6: Initial oxidation pathways of camphene with $\mathrm{NO}_{3}$ as represented in GECKO-A (inorganic products are not shown). 

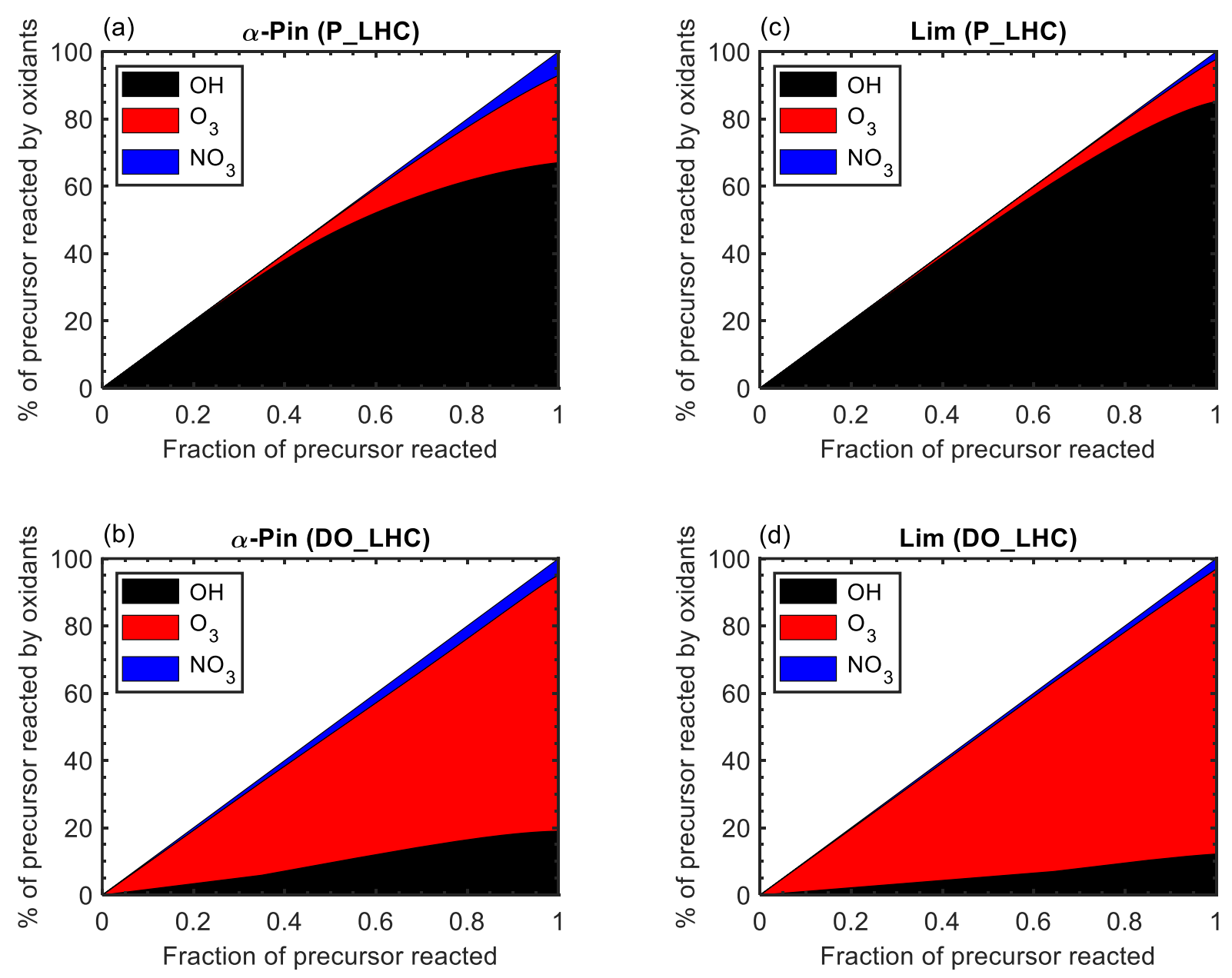

Figure S7: Percentage of precursor consumed by $\mathrm{OH}$ (black), $\mathrm{O}_{3}$ (red), and $\mathrm{NO}_{3}$ (blue) as a function of fraction of precursor reacted for $\alpha$-pinene and limonene under photooxidation and ozonolysis (for lower initial precursor mixing ratio of $50 \mathrm{ppb}$ ).

Figure S7 shows the percentage of the simulated precursor consumed by the three main oxidants: hydroxyl radical $(\mathrm{OH})$, ozone $\left(\mathrm{O}_{3}\right)$, and nitrate radical $\left(\mathrm{NO}_{3}\right)$. Under photooxidation, both $\alpha$-pinene and limonene initially react predominantly with $\mathrm{OH}$. As the reaction progresses (after $\sim 30 \%$ of the precursor is reacted), removal of the precursor by $\mathrm{O}_{3}$ and $\mathrm{NO}_{3}$ begins to grow until the precursor is completely reacted. The results in Fig. S7a indicate that $\sim 67 \%$ of $\alpha$-pinene is removed by $\mathrm{OH}, 25 \%$ by $\mathrm{O}_{3}$, and $\sim 8 \%$ by $\mathrm{NO}_{3}$; similarly, as shown in Fig. $\mathrm{S} 7 \mathrm{c} 85 \%$ of limonene is removed by $\mathrm{OH}, 12 \%$ by $\mathrm{O}_{3}$ and $3 \%$ by $\mathrm{NO}_{3}$ during photooxidation. For $\alpha$-pinene ozonolysis, the consumption is largely by $\mathrm{O}_{3}(\sim 75 \%)$ and $\mathrm{OH}(\sim 20 \%)$, to a lesser extent by $\mathrm{NO}_{3}(\sim 5 \%)$; for limonene, consumption is dominated by $\mathrm{O}_{3}(\sim 85 \%)$, followed by $\mathrm{OH}(\sim 10 \%)$, and $\mathrm{NO}_{3}(\sim 5 \%)$. Unlike in many chamber experiments, there is no $\mathrm{OH}$ scrubber in the simulations. Also, as $\mathrm{NO}_{3}$ is formed by reaction of $\mathrm{O}_{3}$ with $\mathrm{NO}_{2}$ during the dark ozonolysis simulation, a small percentage of the precursor reacts with $\mathrm{NO}_{3}$ since no light is available to photolyze the $\mathrm{NO}_{3}$. 

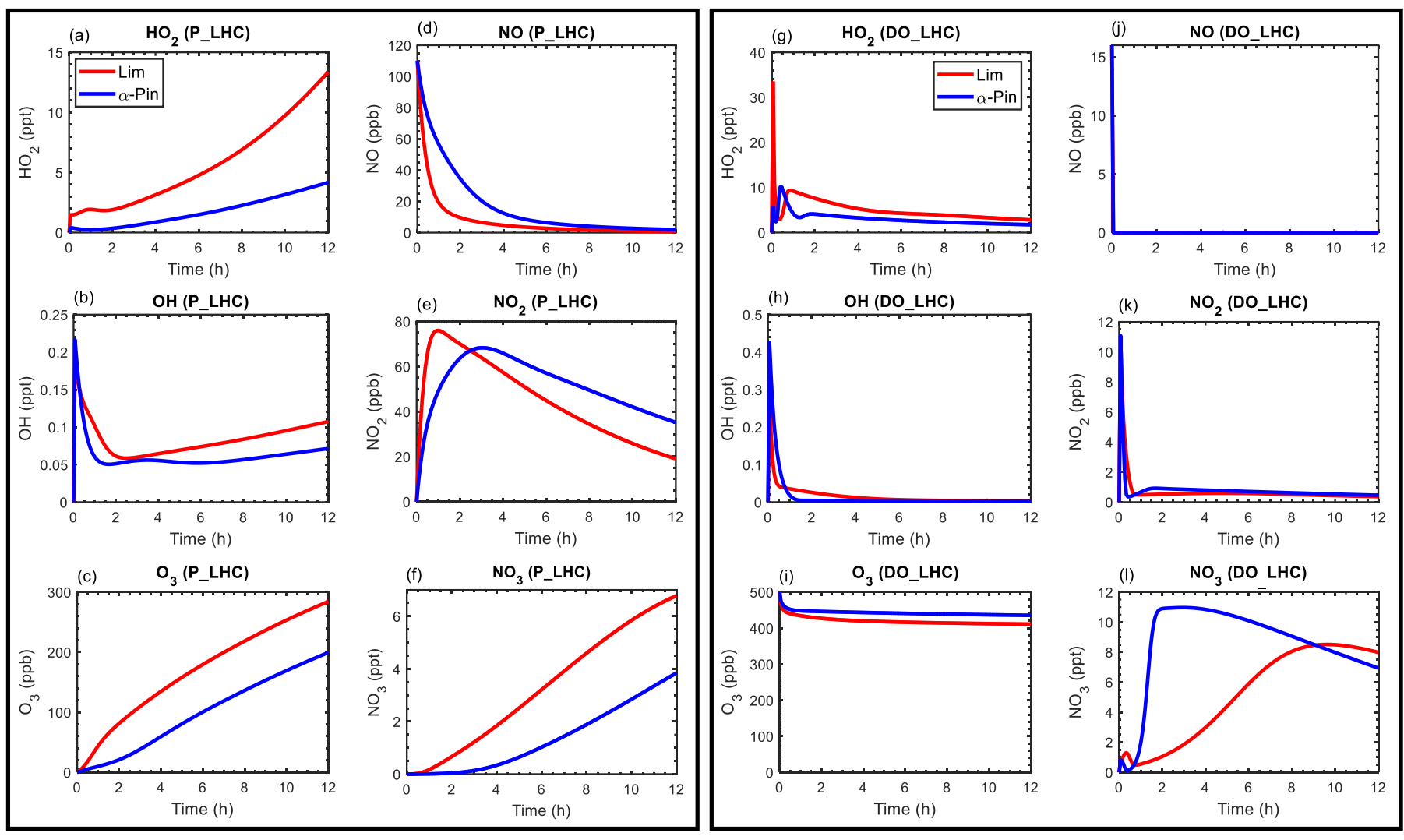

Figure S8: The mixing ratios of $\mathrm{HO}_{2}, \mathrm{OH}, \mathrm{O}_{3}, \mathrm{NO}, \mathrm{NO}_{2}$, and $\mathrm{NO}_{3}$ as a function of time for $\alpha$-pinene (blue line) and limonene (red line) (with the low initial hydrocarbon (LHC) mixing ratio of $50 \mathrm{ppb}$ ) during photooxidation (P) and dark ozonolysis (DO) simulations. 

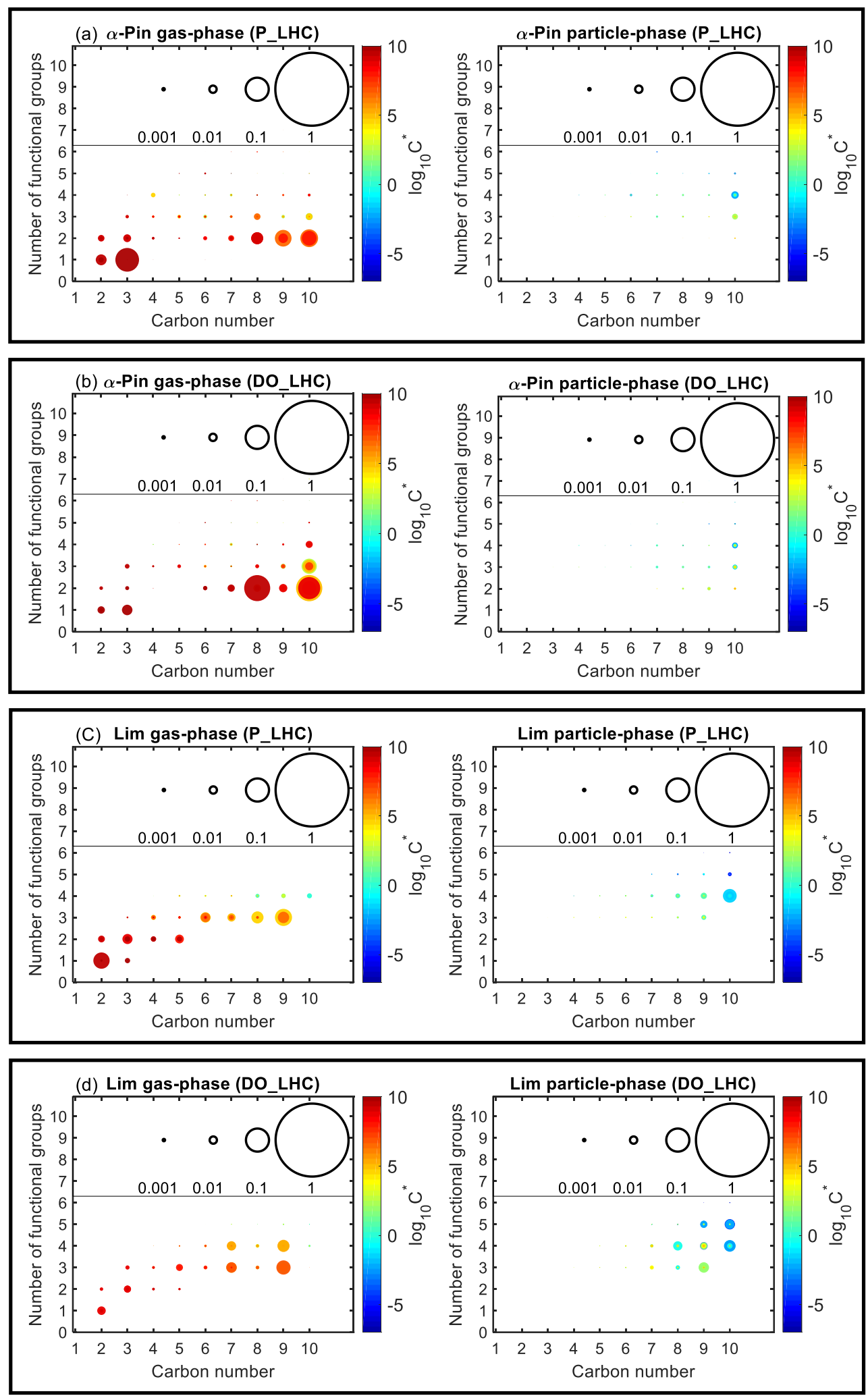

Figure S9: Number of functional groups associated with gas- and particle-phase species as a function of carbon number. Results are shown for camphene, $\alpha$-pinene, and limonene after 12 hours of oxidation under photooxidation (P) and dark ozonolysis (DO) with lower hydrocarbon (LHC) mixing ratio of $50 \mathrm{ppb}$. The markers are sized by the ratio of their mixing ratio (in ppbC) to the initial mixing ratio of the precursor (in ppbC). The colors of the markers are scaled by volatility (represented by saturation concentration, $\mathrm{C} *$ ). 


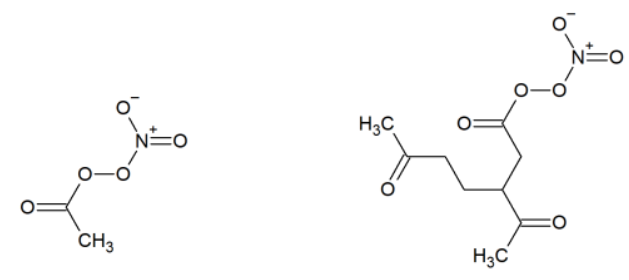

1-(nitroperoxy)ethan-1-one Molecular Formula: $\mathrm{C}_{2} \mathrm{H}_{3} \mathrm{NO}_{5}$

3-acetyl-1-(nitroperoxy)heptane1,6-dione

Molecular Formula: $\mathrm{C}_{9} \mathrm{H}_{13} \mathrm{NO}_{7}$

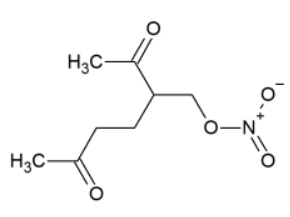

2-acetyl-5-oxohexyl nitrate

Molecular Formula: $\mathrm{C}_{8} \mathrm{H}_{13} \mathrm{NO}_{5}$

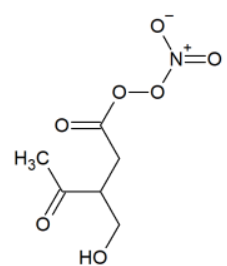

3-(hydroxymethyl)-1-(nitroperoxy) pentane-1,4-dione

Molecular Formula: $\mathrm{C}_{6} \mathrm{H}_{9} \mathrm{NO}_{7}$

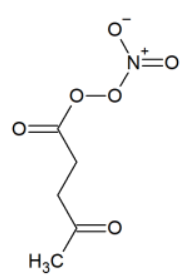

1-(nitroperoxy)pentane-1,4-dione Molecular Formula: $\mathrm{C}_{5} \mathrm{H}_{7} \mathrm{NO}$

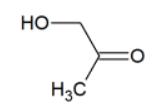

1-hydroxypropan-2-one

Molecular Formula: $\mathrm{C}_{3} \mathrm{H}_{6} \mathrm{O}_{2}$

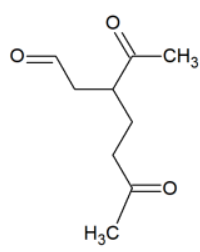

3-acetyl-6-oxoheptanal

Molecular Formula: $\mathrm{C}_{9} \mathrm{H}_{14} \mathrm{O}_{3}$

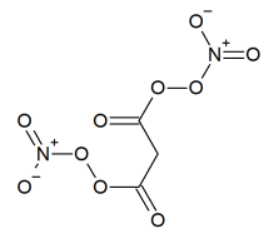

1,3-bis(nitroperoxy)propane-1,3-dione

Molecular Formula: $\mathrm{C}_{3} \mathrm{H}_{2} \mathrm{~N}_{2} \mathrm{O}_{10}$

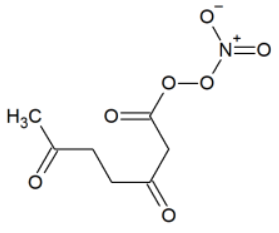

1-(nitroperoxy)heptane-1,3,6-trione

Molecular Formula: $\mathrm{C}_{7} \mathrm{H}_{9} \mathrm{NO}_{7}$

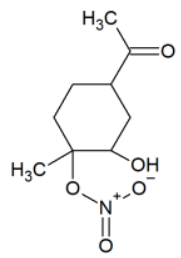

4-acetyl-2-hydroxy-1-methylcyclo hexyl nitrate

Molecular Formula: $\mathrm{C}_{9} \mathrm{H}_{15} \mathrm{NO}_{5}$

Figure S10: Top 10 gas-phase products from limonene photooxidation at the end of the low hydrocarbon (P_LHC) simulation.

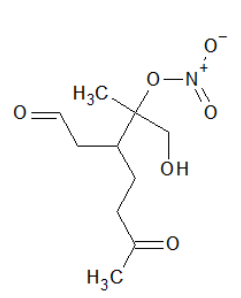

1-hydroxy-2-methyl-6-oxo-3-(2ox oethyl)heptan-2-yl nitrate

Molecular Formula: $\mathrm{C}_{10} \mathrm{H}_{17} \mathrm{NO}_{6}$

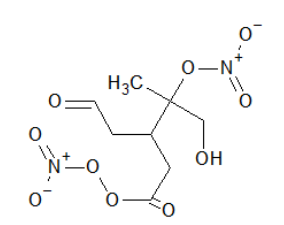

1-hydroxy-2-methyl-5-(nitroperoxy)-5oxo-3-(2-oxoethyl)pentan-2-yl nitrate

Molecular Formula: $\mathrm{C}_{8} \mathrm{H}_{12} \mathrm{~N}_{2} \mathrm{O}_{10}$

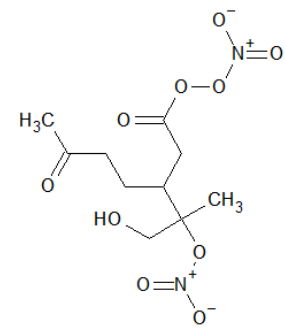

1-hydroxy-2-methyl-3-[2-(nitroperoxy)2-ox oethyl]-6-oxoheptan-2-yl nitrate Molecular Formula: $\mathrm{C}_{10} \mathrm{H}_{16} \mathrm{~N}_{2} \mathrm{O}_{10}$

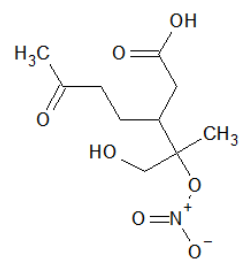

3-[1-hydroxy-2-(nitrooxy)propan2-yl]-6-oxoheptanoic acid Molecular Formula: $\mathrm{C}_{10} \mathrm{H}_{17} \mathrm{NO}_{7}$

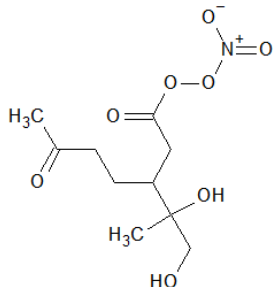

3-(1,2-dihydroxypropan-2-yl)-1(nitroperoxy)heptane-1,6-dione Molecular Formula: $\mathrm{C}_{10} \mathrm{H}_{17} \mathrm{NO}_{8}$

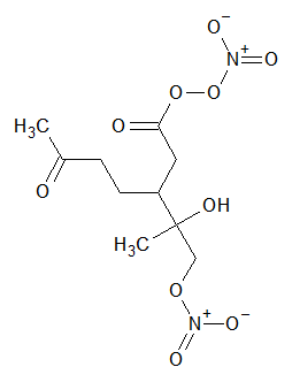

2-hydroxy-2-methyl-3-[2-(nitroperoxy) 2-oxoethyl]-6-oxoheptyl nitrate

Molecular Formula: $\mathrm{C}_{10} \mathrm{H}_{16} \mathrm{~N}_{2} \mathrm{O}_{10}$

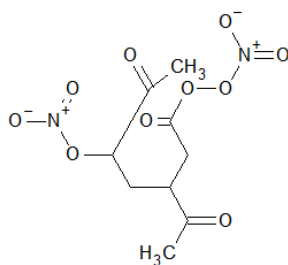

5-acetyl-7-(nitroperoxy)-2, 7-dioxoheptan-3-yl nitrate Molecular Formula: $\mathrm{C}_{9} \mathrm{H}_{12} \mathrm{~N}_{2} \mathrm{O}_{10}$

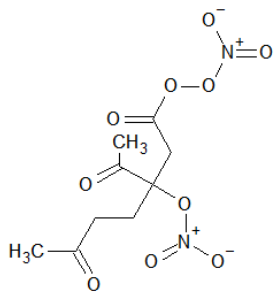

3 -acetyl-1-(nitroperoxy)-1,6-dioxo heptan-3-yl nitrate

Molecular Formula: $\mathrm{C}_{9} \mathrm{H}_{12} \mathrm{~N}_{2} \mathrm{O}_{10}$

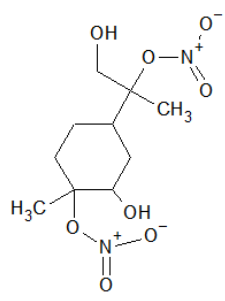

1-hydroxy-2-[3-hydroxy-4-methyl-4-(nitro oxy)cyclohexyl]propan-2-yl nitrate Molecular Formula: $\mathrm{C}_{10} \mathrm{H}_{18} \mathrm{~N}_{2} \mathrm{O}_{8}$

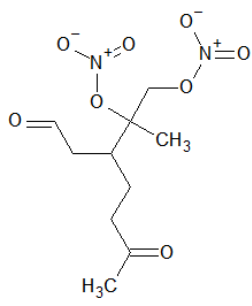

2-methyl-6-oxo-3-(2-ox oethyl) heptane-1,2-diyl dinitrate Molecular Formula: $\mathrm{C}_{10} \mathrm{H}_{16} \mathrm{~N}_{2} \mathrm{O}_{8}$

Figure S11: Top 10 particle-phase products from limonene photooxidation at the end of the low hydrocarbon (P_LHC) simulation. 


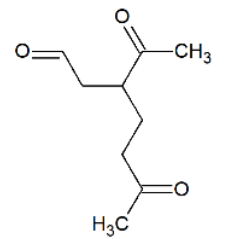

3-acetyl-6-oxoheptanal

Molecular Formula: $\mathrm{C}_{9} \mathrm{H}_{14} \mathrm{O}_{3}$
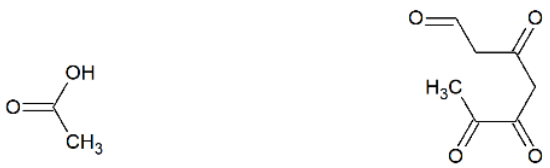

acetic acid

Molccular Formula: $\mathrm{C}_{2} \mathrm{H}_{4} \mathrm{O}_{2}$

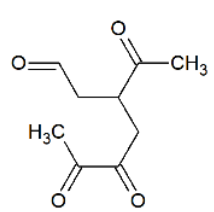

3-acetyl-5,6-dioxoheptanal

Molecular Formula: $\mathrm{C}_{9} \mathrm{H}_{12} \mathrm{O}_{4}$

3,5,6-trioxoheptanal

Molecular Formula: $\mathrm{C}_{7} \mathrm{H}_{8} \mathrm{O}_{4}$ 3-acetyl-6-oxoheptanoic acid

Molecular Formula: $\mathrm{C}_{9} \mathrm{H}_{14} \mathrm{O}_{4}$
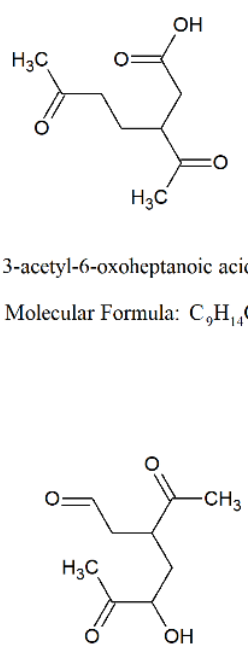

3-acetyl-5-hydroxy-6-oxoheptanal

Molecular Formula: $\mathrm{C}_{9} \mathrm{H}_{14} \mathrm{O}_{4}$

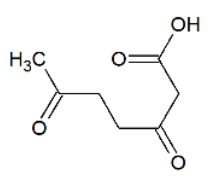

3,6-dioxoheptanoic acid

Molecular Formula: $\mathrm{C}_{7} \mathrm{H}_{10} \mathrm{O}_{4}$

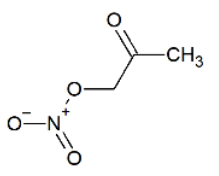

2-oxopropyl nitrate

Molccular Formula: $\mathrm{C}_{3} \mathrm{H}_{5} \mathrm{NO}_{4}$

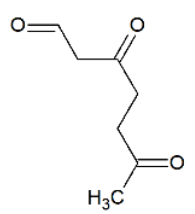

3,6-dioxoheptanal

Molecular Formula: $\mathrm{C}_{7} \mathrm{H}_{10} \mathrm{O}_{3}$

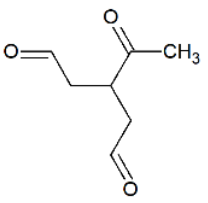

3-acetylpentanedial

Molecular Formula: $\mathrm{C}_{7} \mathrm{H}_{10} \mathrm{O}_{3}$

Figure S12: Top 10 gas-phase products from limonene dark ozonolysis at the end of the low hydrocarbon (DO_LHC) simulation.

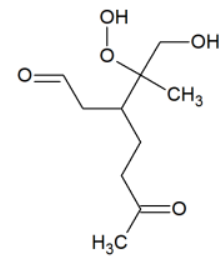

3-(2-hydroperoxy-1-hydroxy propan-2-yl)-6-oxoheptanal

Molecular Formula: $\mathrm{C}_{10} \mathrm{H}_{18} \mathrm{O}_{5}$

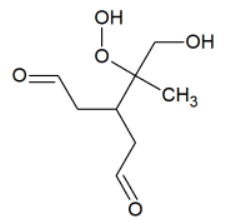

3-(2-hydroperoxy-1-hydroxy propan-2-yl)pentanedial

Molecular Formula: $\mathrm{C}_{8} \mathrm{H}_{14} \mathrm{O}_{5}$

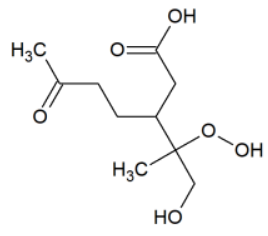

3-(2-hydroperoxy-1-hydroxypropan2-yl)-6-oxoheptanoic acid Molecular Formula: $\mathrm{C}_{10} \mathrm{H}_{18} \mathrm{O}_{6}$

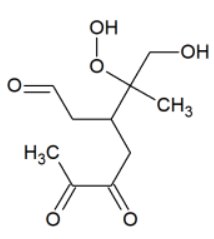

3-(2-hydroperoxy-1-hydroxypropan2-yl)-5,6-dioxoheptanal

Molecular Formula: $\mathrm{C}_{10} \mathrm{H}_{16} \mathrm{O}_{6}$

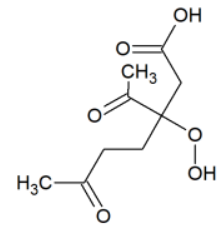

3-acetyl-3-hydroperoxy-6oxoheptanoic acid

Molecular Formula: $\mathrm{C}_{9} \mathrm{H}_{14} \mathrm{O}_{6}$

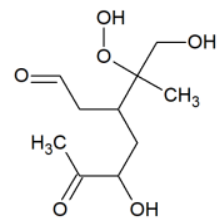

3-(2-hydroperoxy-1-hydroxypropan2-yl)-5-hydroxy-6-oxoheptanal

Molecular Formula: $\mathrm{C}_{10} \mathrm{H}_{18} \mathrm{O}_{6}$

3-acetyl-6-oxoheptanoic acid

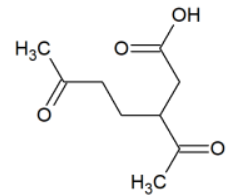

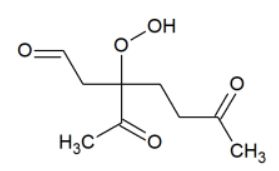

3-acetyl-3-hydroperoxy-5,6dioxoheptanal

Molecular Formula: $\mathrm{C}_{9} \mathrm{H}_{12} \mathrm{O}_{6}$

Molecular Formula: $\mathrm{C}_{9} \mathrm{H}_{14} \mathrm{O}_{5}$ Molecular Formula: $\mathrm{C}_{9} \mathrm{H}_{14} \mathrm{O}_{4}$

3-acetyl-3-hydroperoxy-6-oxoheptanal

Figure S13: Top 10 particle-phase products from limonene dark ozonolysis at the end of the low hydrocarbon (DO_LHC) simulation. 
Photooxidation low HC (P_LHC)
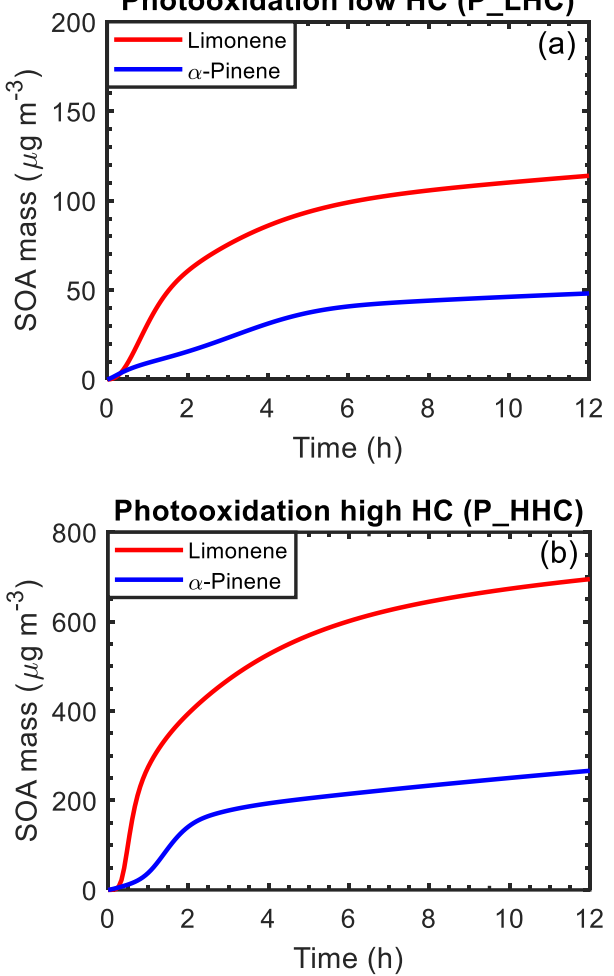

Dark ozonolysis low HC (DO_LHC)
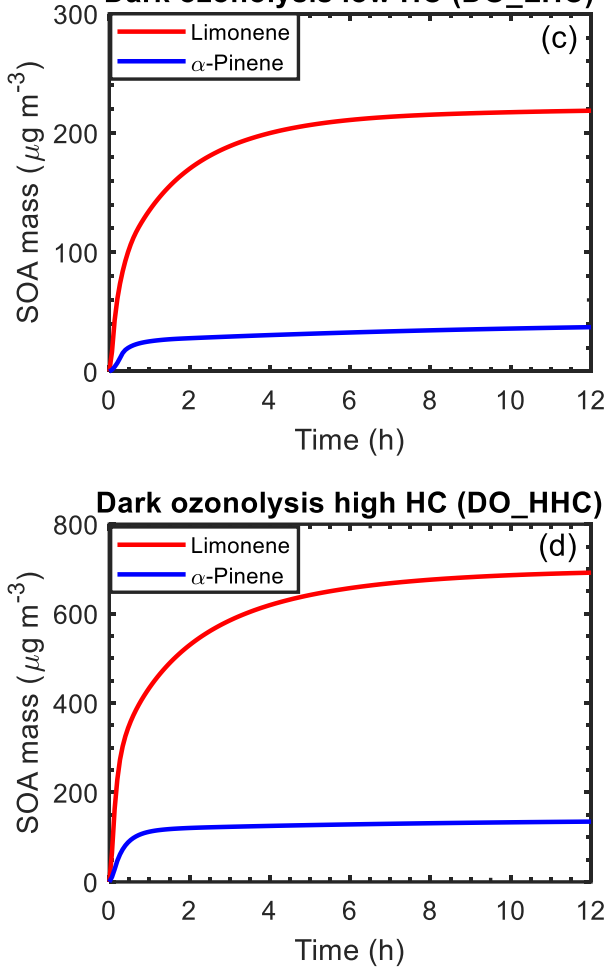

Figure S14: Simulated SOA mass as a function of time for $\alpha$-pinene and limonene during photooxidation and dark ozonolysis with low hydrocarbon mixing ratio (50 ppb).
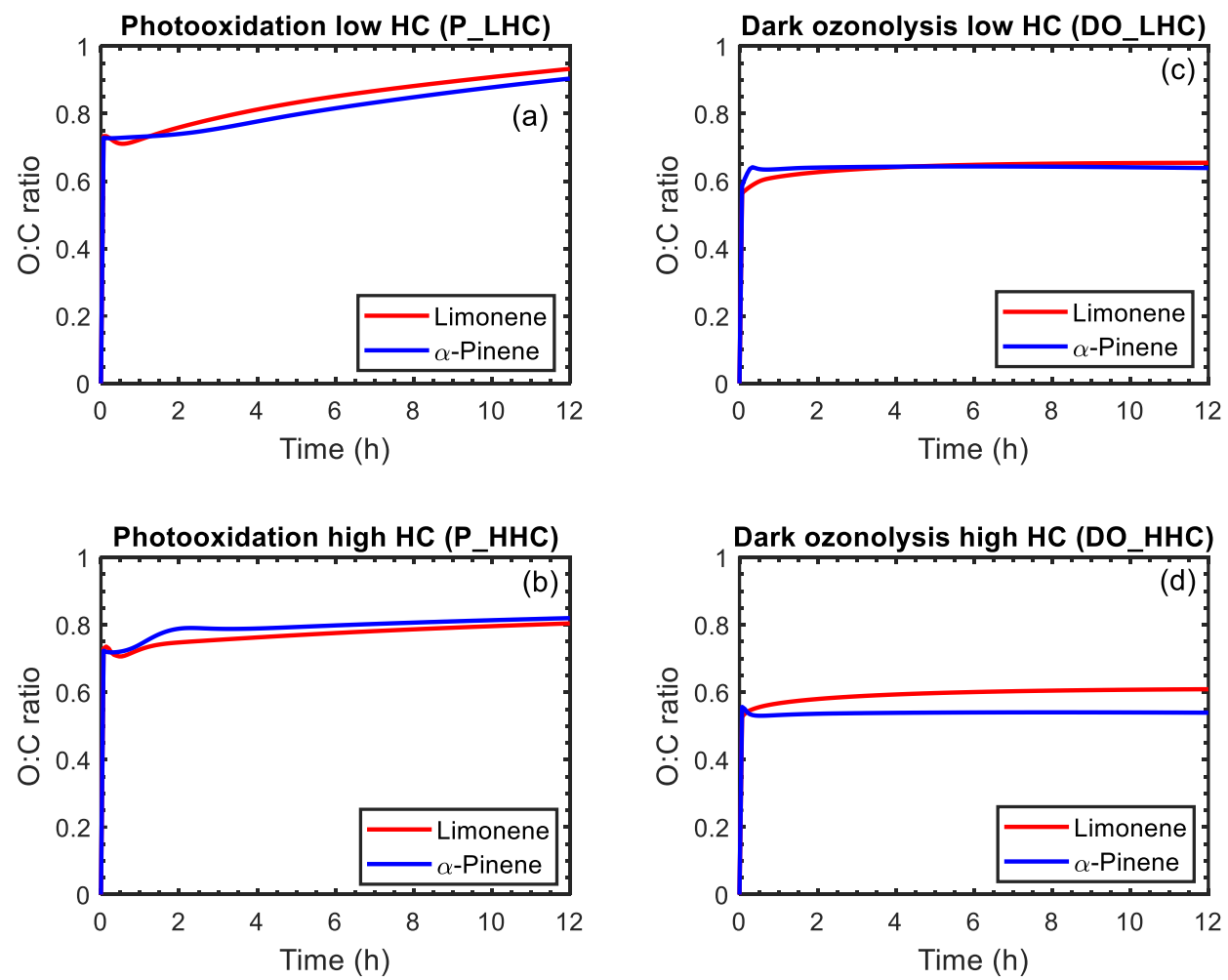

Figure S15: Simulated average $\mathrm{O} / \mathrm{C}$ as a function of time for $\alpha$-pinene and limonene during photooxidation and dark ozonolysis with low hydrocarbon mixing ratio (50 ppb). 

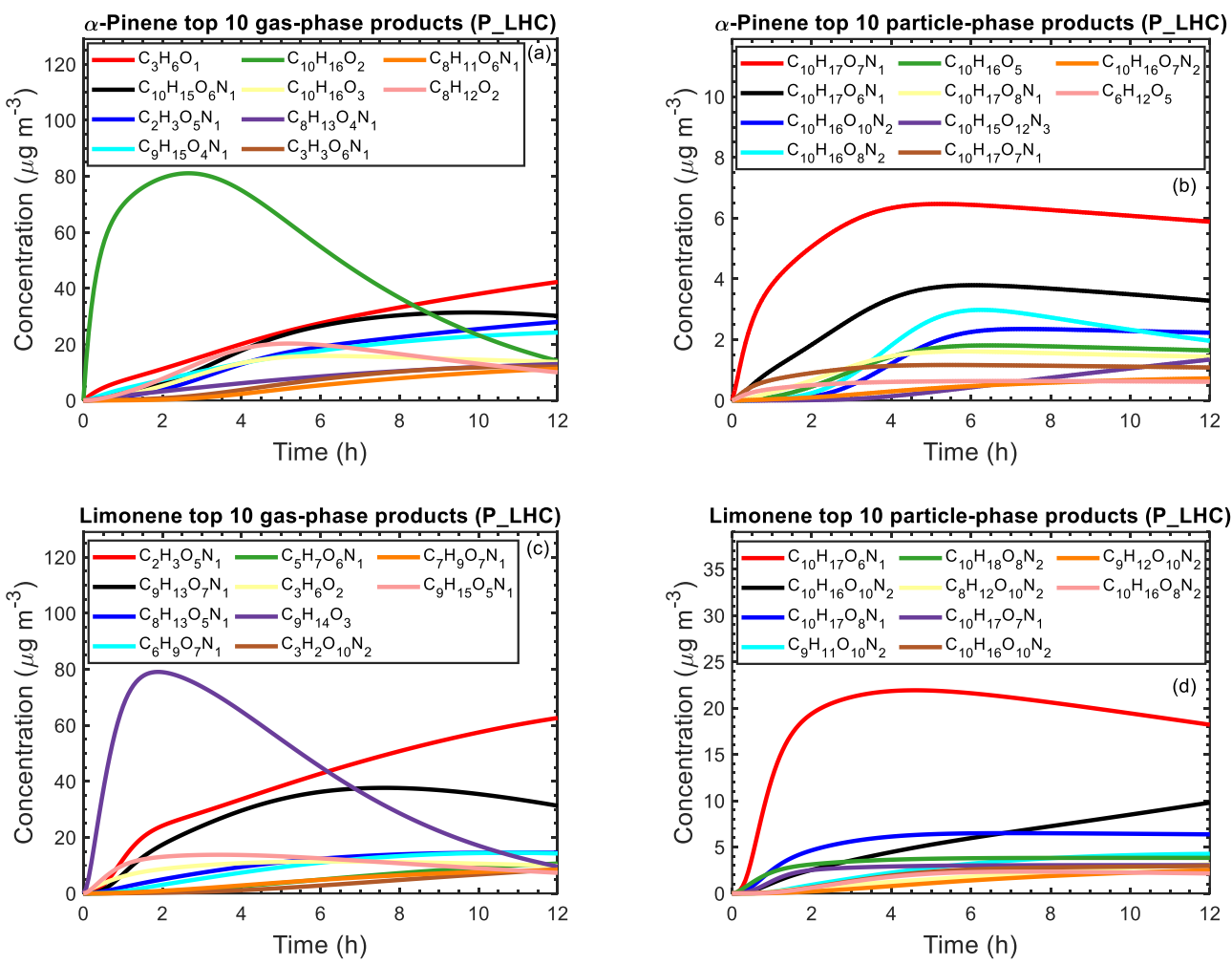

Figure S16: Concentration of top 10 gas- and particle-phase products as a function of time for $\alpha$-pinene and limonene during photooxidation with low hydrocarbon mixing ratio (50 ppb).
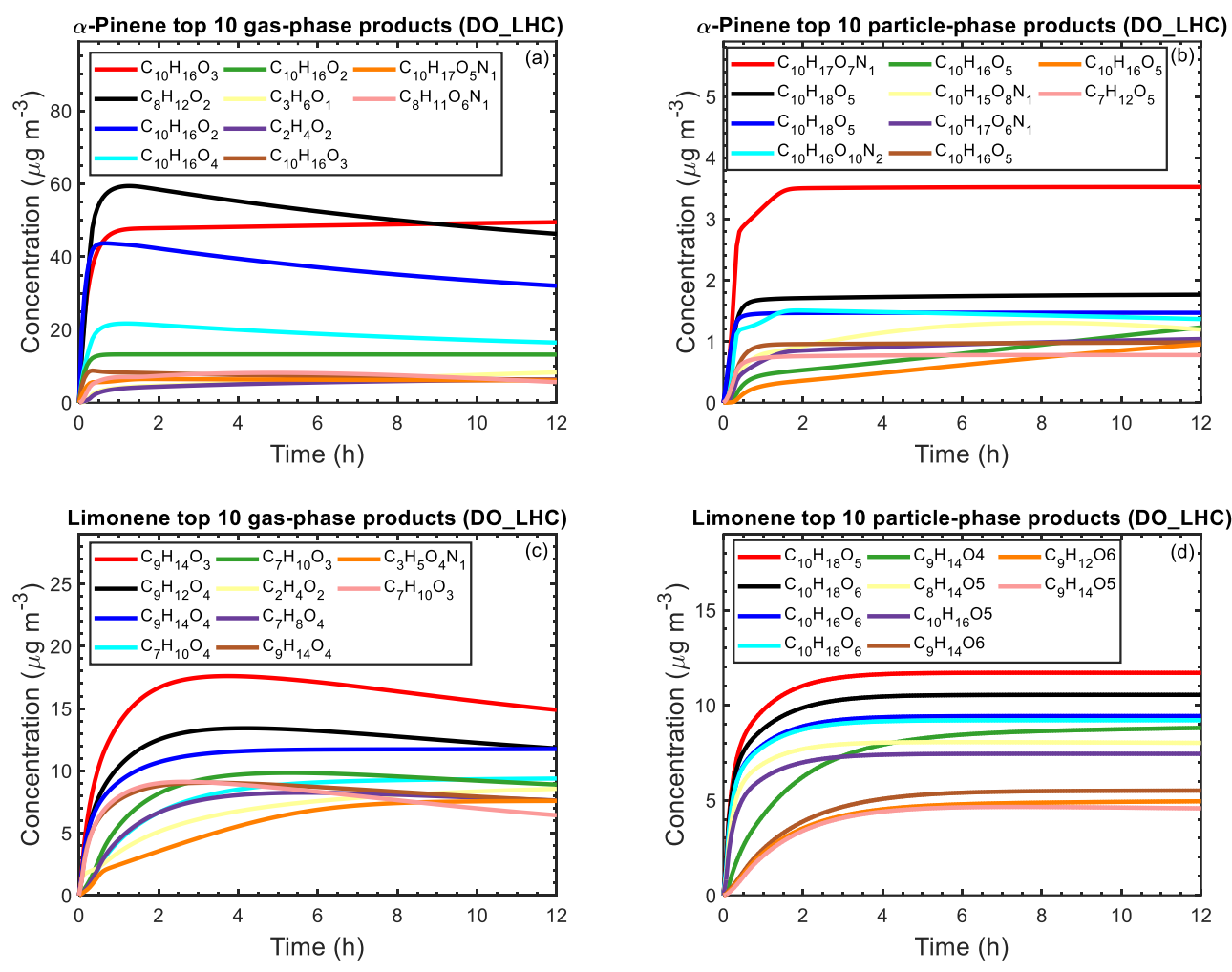

Figure S17: Concentration of top 10 gas- and particle-phase products as a function of time for $\alpha$-pinene and limonene during dark ozonolysis with low hydrocarbon mixing ratio (50 ppb). 


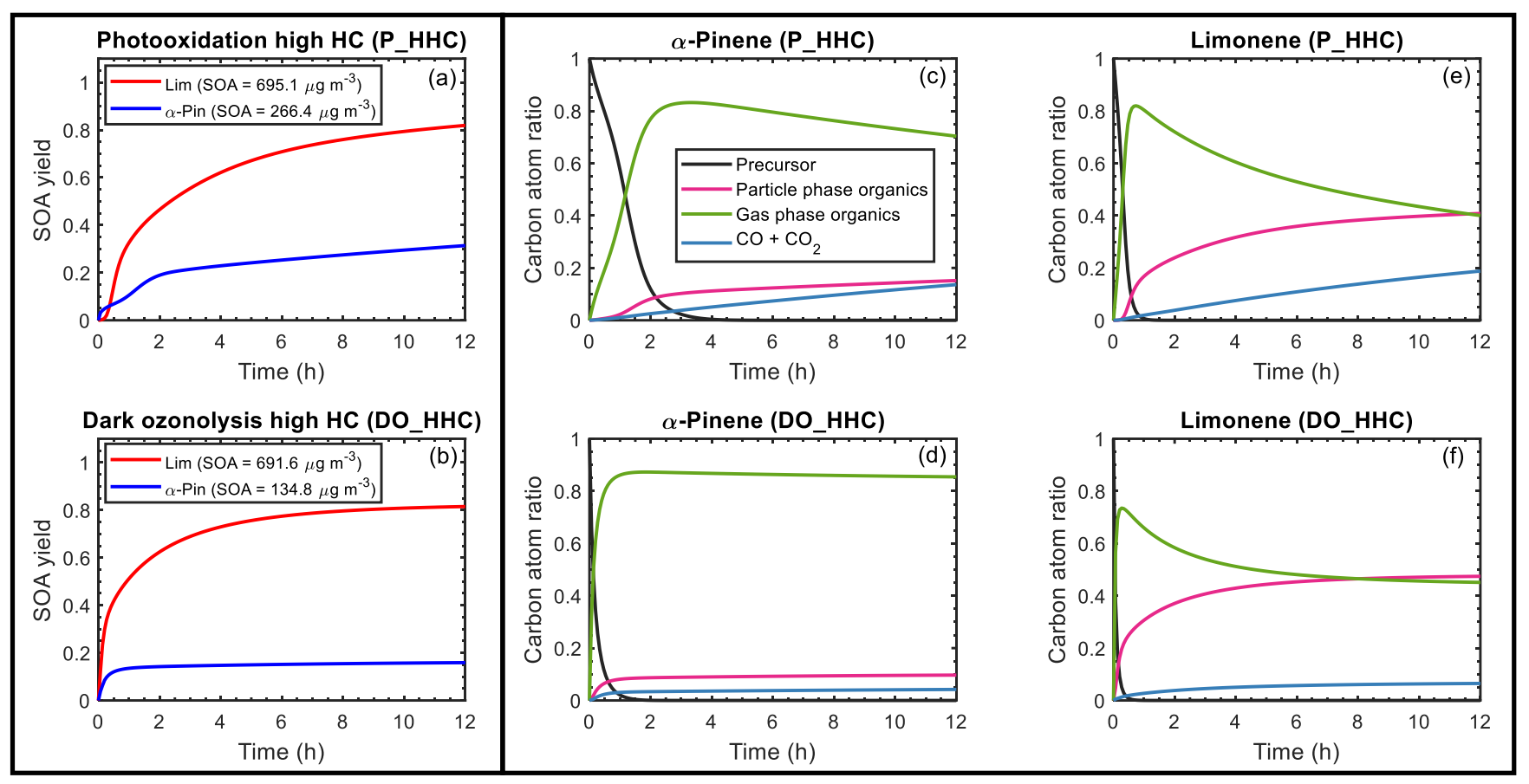

Figure S18: Simulated SOA yield as a function of time (a and b) and carbon budget ( $c$ to $f$ ) for $\alpha$-pinene and limonene during photooxidation (a, c, e) and dark ozonolysis $(b, d, f)$. The SOA yield curve for $\alpha$-pinene is represented by a blue line; limonene is represented by a red line. For the carbon budget plots, the mixing ratios of the precursor (black line), particlephase organics (magenta line), gas-phase organics (green line), and $\mathrm{CO}+\mathrm{CO}_{2}$ (blue line) are expressed as carbon atom ratios (in ppbC)/initial precursor (in ppbC). The results shown are for the high hydrocarbon mixing ratio (150 ppb) simulations. 

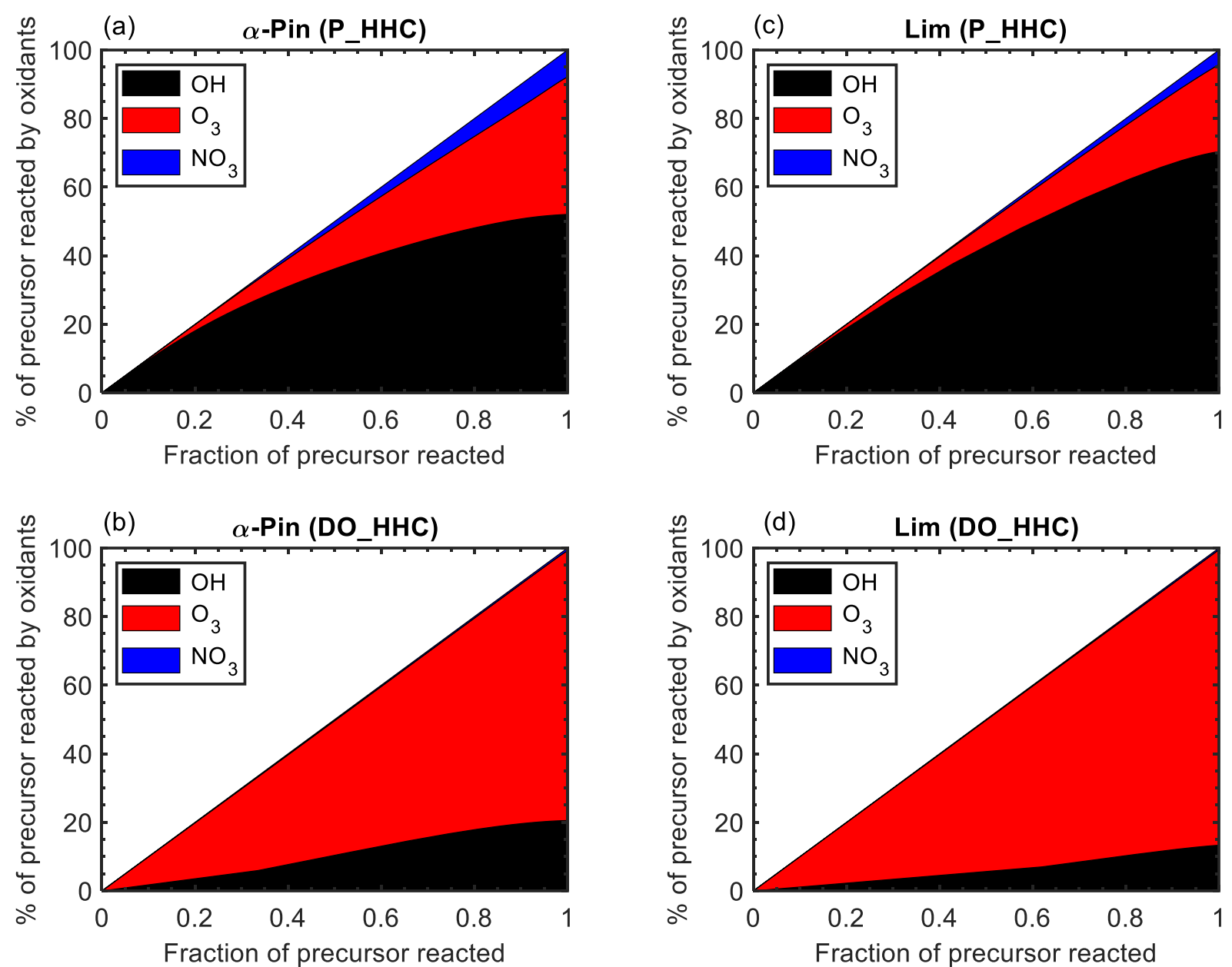

Figure S19: Percentage of precursor consumed by $\mathrm{OH}$ (black), $\mathrm{O}_{3}$ (red), and $\mathrm{NO}_{3}$ (blue) as a function of fraction of precursor reacted for $\alpha$-pinene and limonene under photooxidation and ozonolysis (for higher initial precursor concentration of $150 \mathrm{ppb})$. 

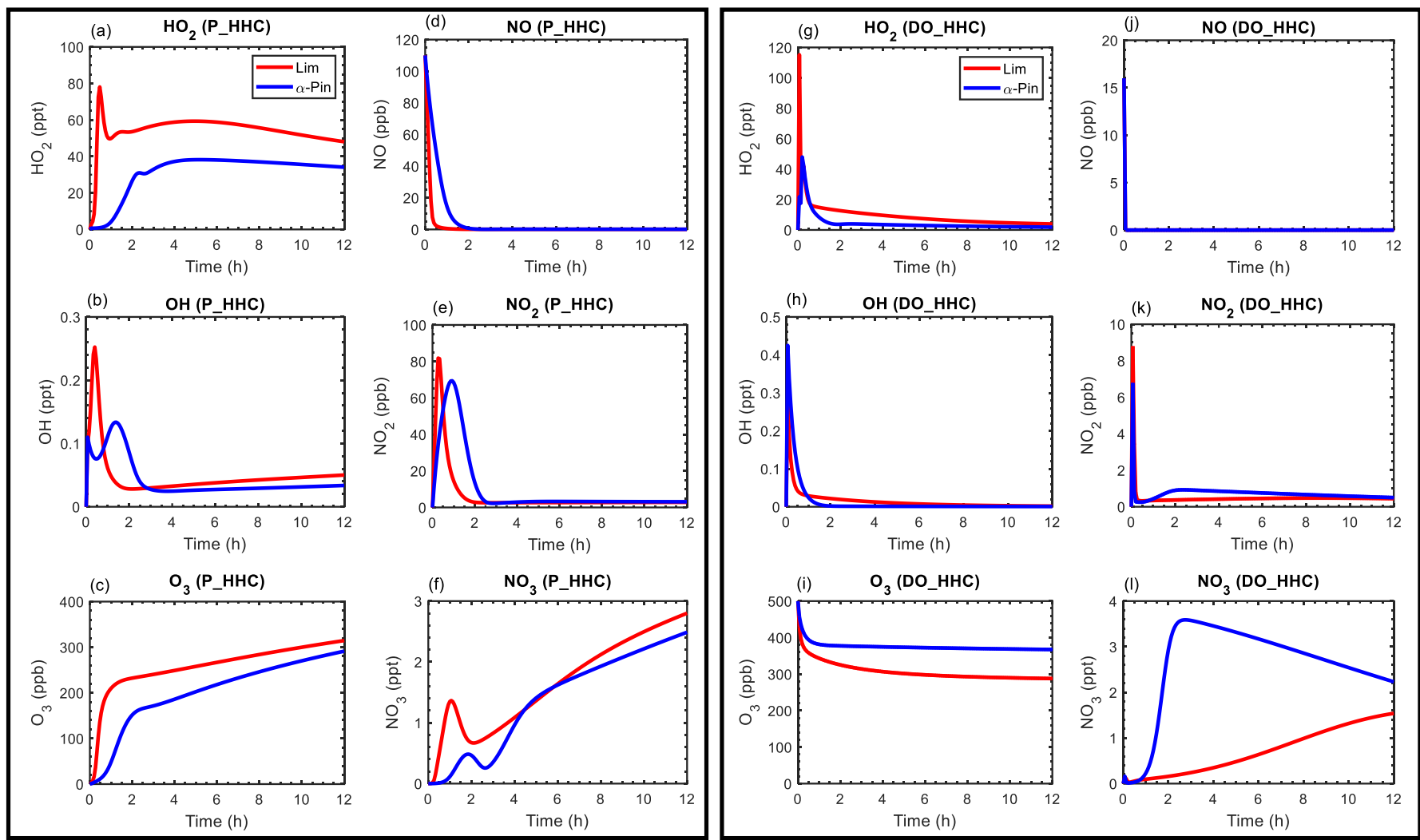

Figure S20: Mixing ratios of $\mathrm{HO}_{2}, \mathrm{OH}, \mathrm{O}_{3}, \mathrm{NO}, \mathrm{NO}_{2}$, and $\mathrm{NO}_{3}$ as function of time for limonene (red line), camphene (black line), and $\alpha$-pinene (blue line) during the photooxidation and ozonolysis (with higher initial hydrocarbon mixing ratio of $150 \mathrm{ppb})$. 

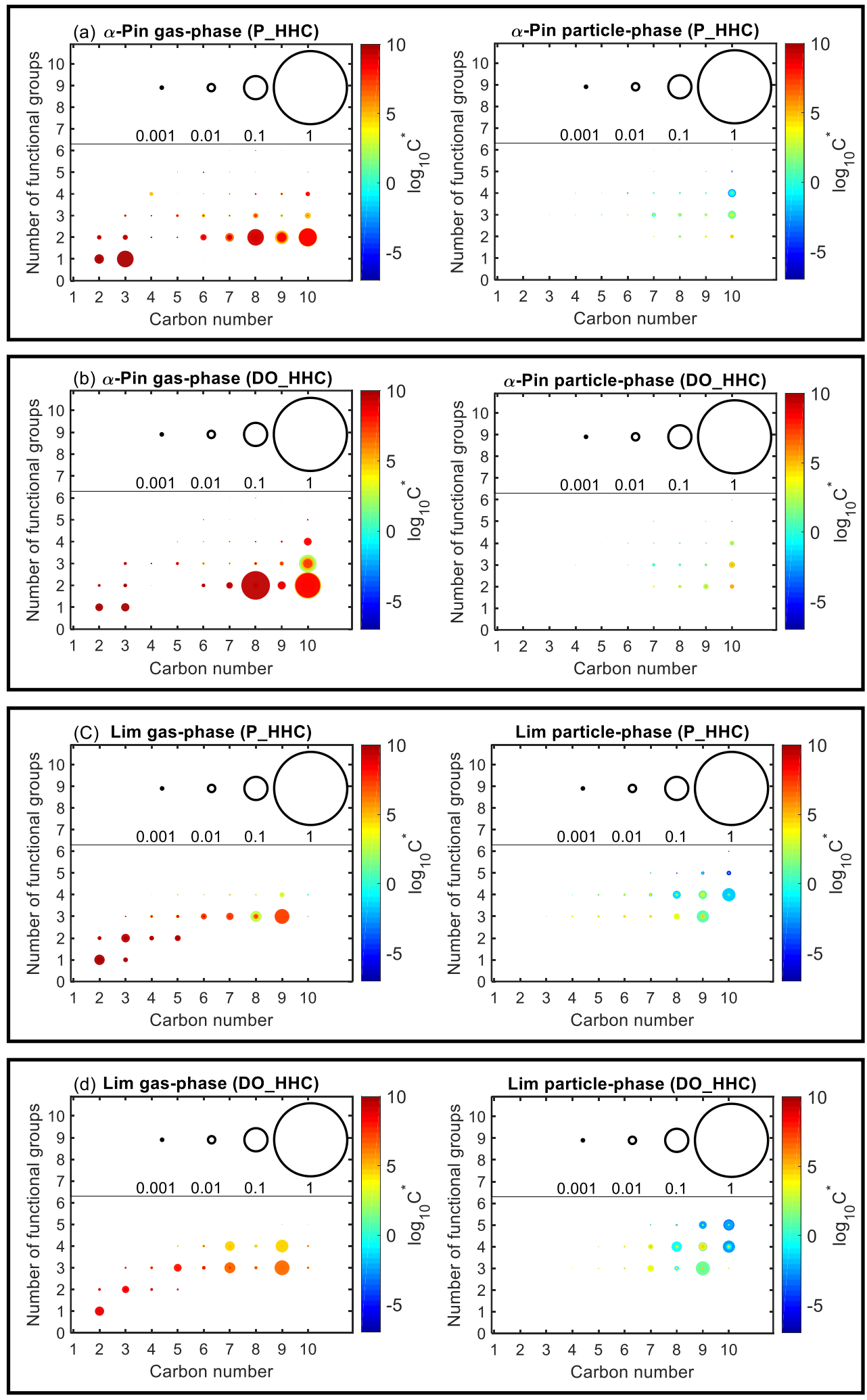

Figure S21: Number of functional groups associated with gas- and particle-phase species as a function of carbon number. Results are shown for camphene, $\alpha$-pinene, and limonene after 12 hours of oxidation under photooxidation (P) and dark ozonolysis (DO) with higher hydrocarbon (LHC) mixing ratio of $150 \mathrm{ppb}$. The markers are sized by the ratio of their mixing ratio (in ppbC) to the initial mixing ratio of the precursor (in ppbC). The colors of the markers are scaled by volatility (represented by saturation concentration, $\mathrm{C} *$ ). 


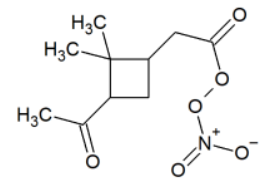

2-(3-acetyl-2,2-dimethylcyclobutyl) -1-(nitroperoxy)ethan-1-one

Molecular Formula: $\mathrm{C}_{10} \mathrm{H}_{15} \mathrm{NO}_{6}$

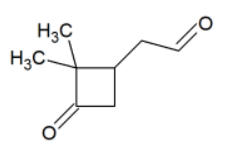

(2,2-dimethyl-3-oxocyclobutyl) acetaldehyde

Molecular Formula: $\mathrm{C}_{8} \mathrm{H}_{12} \mathrm{O}$

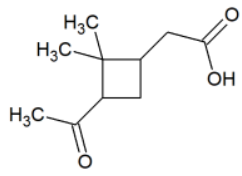

(3-acetyl-2,2-dimethylcyclobutyl) acetic acid

Molecular Formula: $\mathrm{C}_{10} \mathrm{H}_{16} \mathrm{O}_{3}$

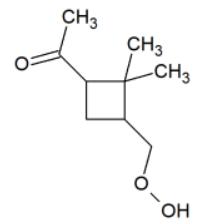

1-[3-(hydroperoxymethyl)-2,2-di methylcyclobutyl] ethan-1-one

Molecular Formula: $\mathrm{C}_{9} \mathrm{H}_{16} \mathrm{O}_{3}$

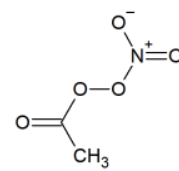

1-(nitroperoxy)ethan-1-one

Molecular Formula: $\mathrm{C}_{2} \mathrm{H}_{3} \mathrm{NO}_{5}$

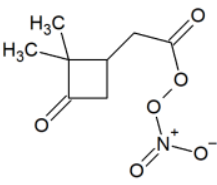

2,2-dimethyl-3-[2-(nitroperoxy) -2-oxoethyl]cyclobutan-1-one

Molecular Formula: $\mathrm{C}_{8} \mathrm{H}_{11} \mathrm{NO}_{6}$
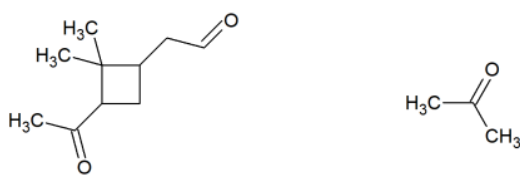

(3-acetyl-2,2-dimethylcyclobutyl) acetaldehyde

Molecular Formula: $\mathrm{C}_{10} \mathrm{H}_{16} \mathrm{O}$

propan-2-one

Molecular Formula: $\mathrm{C}_{3} \mathrm{H}_{6} \mathrm{O}$
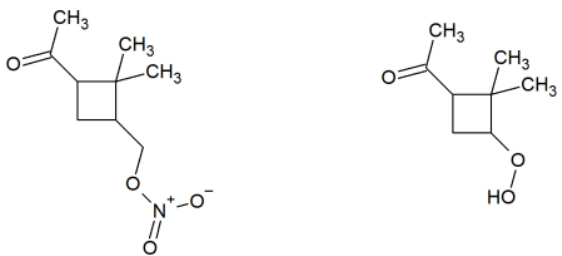

(3-acetyl-2,2-dimethylcyclobutyl methyl nitrate

Molecular Formula: $\mathrm{C}_{9} \mathrm{H}_{15} \mathrm{NO}_{4}$ 1-(3-hydroperoxy-2,2-dimethyl

Molecular Formula: $\mathrm{C}_{8} \mathrm{H}_{14} \mathrm{O}_{3}$ cyclobutyl)ethan-1-one

Figure S22: Top 10 gas-phase products from $\alpha$-pinene photooxidation at the end of the high hydrocarbon (P_HHC) simulations.

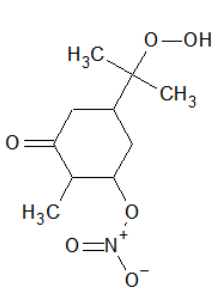

5-(2-hydroperoxypropan-2-yl)-2methyl-3-ox ocyclohexyl nitrate

Molecular Formula: $\mathrm{C}_{10} \mathrm{H}_{17} \mathrm{NO}_{6}$

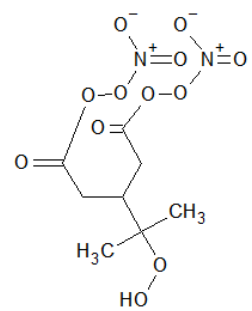

3-(2-hydroperoxypropan-2-yl)-1,5 bis(nitroperoxy)pentane-1,5-dione

Molecular Formula: $\mathrm{C}_{8} \mathrm{H}_{12} \mathrm{~N}_{2} \mathrm{O}_{12}$

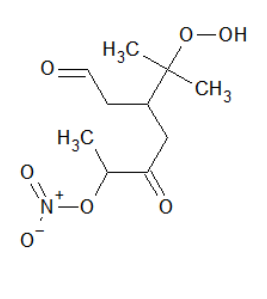

6-hydroperoxy-6-methyl-3-oxo-5(2-oxoethyl)heptan-2-yl nitrate

Molecular Formula: $\mathrm{C}_{10} \mathrm{H}_{17} \mathrm{NO}_{7}$

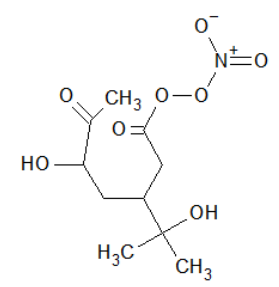

5-hydroxy-3-(2-hydroxypropan-2-yl)1-(nitroperoxy)heptane-1,6-dione

Molecular Formula: $\mathrm{C}_{10} \mathrm{H}_{17} \mathrm{NO}_{8}$

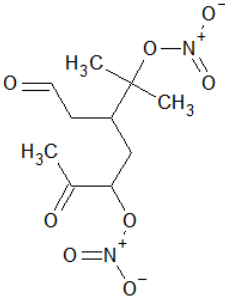

2-methyl-6-oxo-3-(2-oxoethyl) heptane-2,5-diyl dinitrate

Molecular Formula: $\mathrm{C}_{10} \mathrm{H}_{16} \mathrm{~N}_{2} \mathrm{O}_{8}$

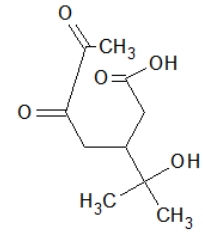

3-(2-hydroxypropan-2-yl)-5,6dioxoheptanoic acid

Molecular Formula: $\mathrm{C}_{10} \mathrm{H}_{16} \mathrm{O}_{5}$

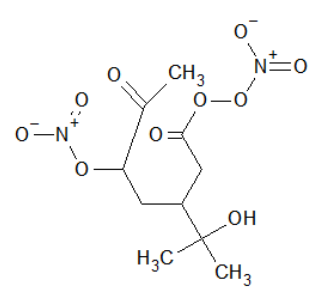

6-hydroxy-6-methyl-5-[2-(nitroperoxy)2-oxoethyl]-2-oxoheptan-3-yl nitrate

Molecular Formula: $\mathrm{C}_{10} \mathrm{H}_{16} \mathrm{~N}_{2} \mathrm{O}_{10}$

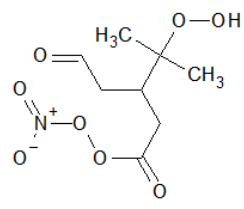

4-hydroperoxy-4-methyl-3-[2-(nitro peroxy)-2-oxoethyl]pentanal

Molecular Formula: $\mathrm{C}_{8} \mathrm{H}_{13} \mathrm{NO}_{8}$

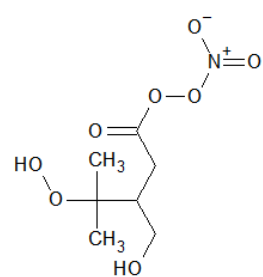

4-hydroperoxy-3-(hydroxymethyl)-4methyl-1-(nitroperoxy)pentan-1-one Molecular Formula: $\mathrm{C}_{7} \mathrm{H}_{13} \mathrm{NO}_{8}$

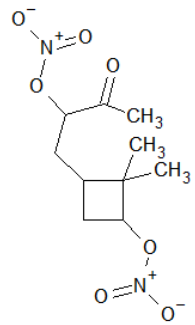

1-[2,2-dimethyl-3-(nitrooxy)cyclo butyl]-3-oxobutan-2-yl nitrate

Molecular Formula: $\mathrm{C}_{10} \mathrm{H}_{10} \mathrm{~N}_{2} \mathrm{O}_{7}$

Figure S23: Top 10 particle-phase products from $\alpha$-pinene photooxidation at the end of the high hydrocarbon (P_HHC) simulations. 


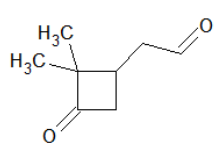

(2,2-dimethyl-3-oxocyclobutyl) acetaldehyde

Molecular Formula: $\mathrm{C}_{8} \mathrm{H}_{12} \mathrm{O}_{2}$

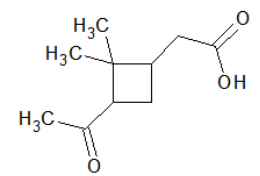

(3-acetyl-2,2-dimethylcyclobutyl) acetic acid

Molecular Formula: $\mathrm{C}_{10} \mathrm{H}_{16} \mathrm{O}_{3}$

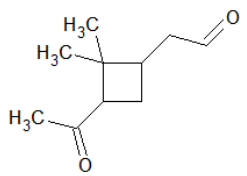

(3-acetyl-2,2-dimethylcyclobutyl) acetaldehyde

Molecular Formula: $\mathrm{C}_{10} \mathrm{H}_{16} \mathrm{O}_{2}$

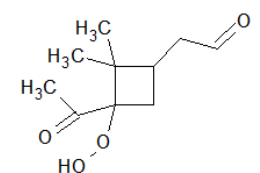

(3-acetyl-3-hydroperoxy-2,2-dimethyl cyclobutyl)acetaldehyde

Molecular Formula: $\mathrm{C}_{10} \mathrm{H}_{16} \mathrm{O}_{4}$

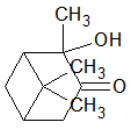

2-hydroxy-2,6,6-trimethylbicycl o[3.1.1] heptan-3-one

Molecular Formula: $\mathrm{C}_{10} \mathrm{H}_{16} \mathrm{O}_{2}$

$$
\mathrm{O}=\mathrm{CH}_{3}^{\mathrm{OH}}
$$

acetic acid

Molecular Formula: $\mathrm{C}_{2} \mathrm{H}_{4} \mathrm{O}_{2}$

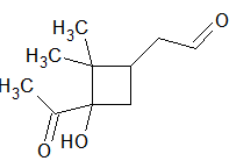

(3-acetyl-3-hydroxy-2,2-dimethyl cyclobutyl)acetaldehyde

Molecular Formula: $\mathrm{C}_{10} \mathrm{H}_{16} \mathrm{O}_{3}$

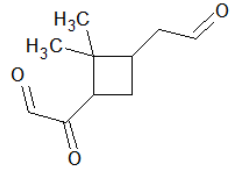

[2,2-dimethyl-3-(2-oxoethyl)cyclo butyl](oxo)acetaldehyde

Molecular Formula: $\mathrm{C}_{10} \mathrm{H}_{14} \mathrm{O}_{3}$

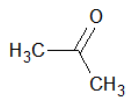

propan-2-one

Molecular Formula: $\mathrm{C}_{3} \mathrm{H}_{6} \mathrm{O}$

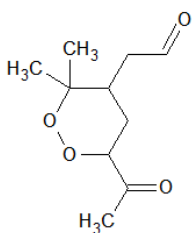

(6-acetyl-3,3-dimethyl-1,2-diox an4-yl)acetaldehyde

Molecular Formula: $\mathrm{C}_{10} \mathrm{H}_{16} \mathrm{O}_{4}$

Figure S24: Top 10 gas-phase products from $\alpha$-pinene dark ozonolysis at the end of the high hydrocarbon (DO_HHC) simulations.

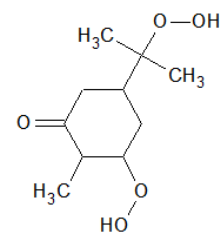

3-hydroperoxy-5-(2-hydroperoxypropan2-yl)-2-methylcyclohex an-1-one

Molecular Formula: $\mathrm{C}_{10} \mathrm{H}_{18} \mathrm{O}_{5}$

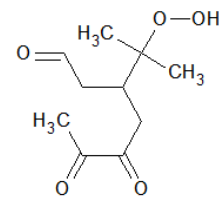

3-(2-hydroperoxypropan-2-yl)5,6-dioxoheptanal

Molecular Formula: $\mathrm{C}_{10} \mathrm{H}_{16} \mathrm{O}_{5}$

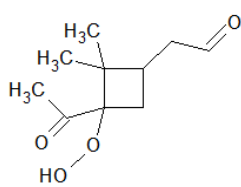

(3-acetyl-3-hydroperoxy-2,2-dimethyl cyclobutyl)acetaldehyde

Molecular Formula: $\mathrm{C}_{10} \mathrm{H}_{16} \mathrm{O}_{4}$

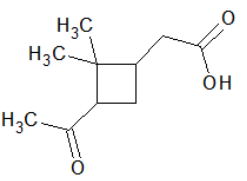

(3-acetyl-2,2-dimethylcyclobutyl) acetic acid

Molecular Formula: $\mathrm{C}_{10} \mathrm{H}_{16} \mathrm{O}_{3}$

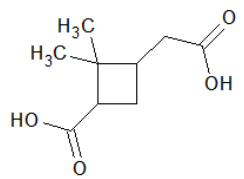

3-(carboxymethyl)-2,2-dimethyl cyclobutane-1-carboxylic acid

Molecular Formula: $\mathrm{C}_{9} \mathrm{H}_{14} \mathrm{O}_{4}$

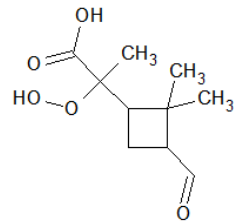

2-(3-formyl-2,2-dimethylcyclobut yl)-2-hydroperoxypropanoic acid Molecular Formula: $\mathrm{C}_{10} \mathrm{H}_{16} \mathrm{O}_{5}$

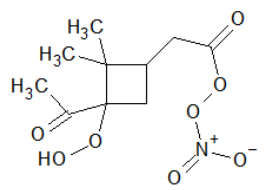

2-(3-acetyl-3-hydroperoxy-2,2-dimethyl cyclobutyl)-1-(nitroperoxy)ethan-1-one

Molecular Formula: $\mathrm{C}_{10} \mathrm{H}_{15} \mathrm{NO}_{8}$

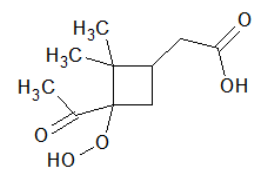

(3-acetyl-3-hydroperoxy-2,2-di methylcyclobutyl)acetic acid Molecular Formula: $\mathrm{C}_{10} \mathrm{H}_{16} \mathrm{O}_{5}$

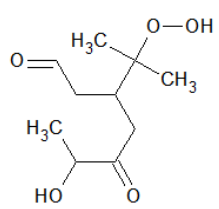

3-(2-hydroperoxypropan-2-yl)-6hydroxy-5-oxoheptanal

Molecular Formula: $\mathrm{C}_{10} \mathrm{H}_{18} \mathrm{O}_{5}$

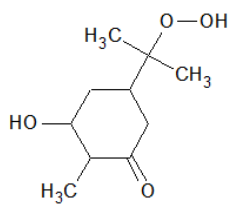

5-(2-hydroperoxypropan-2-yl)-3-1 ydroxy-2-methylcyclohexan-1-one Molecular Formula: $\mathrm{C}_{10} \mathrm{H}_{18} \mathrm{O}_{4}$

Figure S25: Top 10 particle-phase products from $\alpha$-pinene dark ozonolysis at the end of the high hydrocarbon (DO_HHC) simulations. 


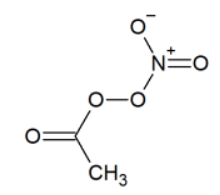

1-(nitroperoxy)ethan-1-one

Molecular Formula: $\mathrm{C}_{2} \mathrm{H}_{3} \mathrm{NO}_{5}$

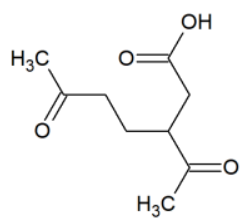

3-acetyl-6-oxoheptanoic acid

Molecular Formula: $\quad \mathrm{C}_{9} \mathrm{H}_{14} \mathrm{O}_{4}$

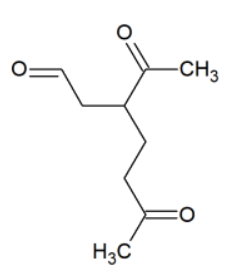

3-acetyl-6-oxoheptanal

Molecular Formula: $\mathrm{C}_{9} \mathrm{H}_{14} \mathrm{O}_{3}$

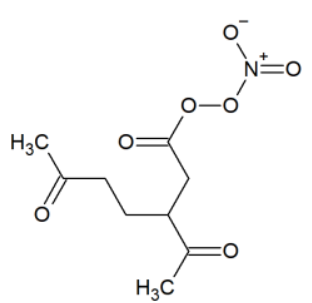

3-acetyl-1-(nitroperoxy) heptane-1,6-dione

Molecular Formula: $\mathrm{C}_{9} \mathrm{H}_{13} \mathrm{NO}_{7}$

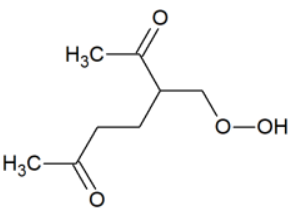

3-(hydroperoxymethyl)heptane2,6-dione

Molecular Formula: $\mathrm{C}_{8} \mathrm{H}_{14} \mathrm{O}_{4}$

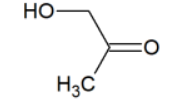

1-hydroxypropan-2-one

Molecular Formula: $\mathrm{C}_{3} \mathrm{H}_{6} \mathrm{O}_{2}$

Figure S26: Top 10 gas-phase products from limonene photooxidation at the end of the high hydrocarbon (P_HHC).

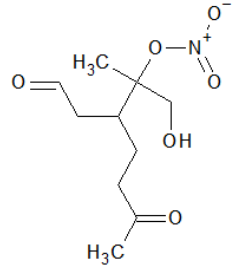

1-hydroxy-2-methyl-6-oxo-3-(2oxoethyl)heptan-2-yl nitrate

Molecular Formula: $\mathrm{C}_{10} \mathrm{H}_{17} \mathrm{NO}_{6}$

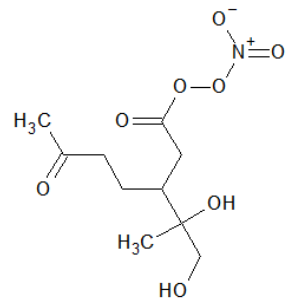

3-(1,2-dihydroxypropan-2-yl)-1(nitroperoxy)heptane-1,6-dione

Molecular Formula: $\mathrm{C}_{10} \mathrm{H}_{17} \mathrm{NO}_{8}$

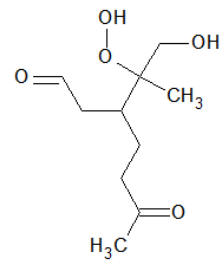

3-(2-hydroperoxy-1-hydroxy propan-2-yl)-6-oxoheptanal Molecular Formula: $\mathrm{C}_{10} \mathrm{H}_{18} \mathrm{O}_{5}$

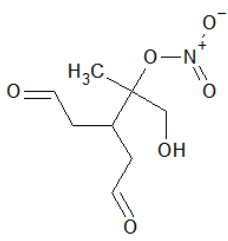

1-hydroxy-2-methyl-5-oxo-3-(2oxoethyl)pentan-2-yl nitrate Molecular Formula: $\mathrm{C}_{8} \mathrm{H}_{13} \mathrm{NO}_{6}$

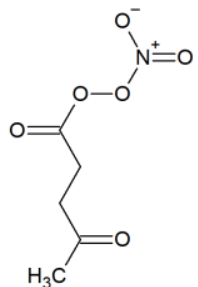

1-(nitroperoxy)pentane-1,4-dione

Molecular Formula: $\quad \mathrm{C}_{5} \mathrm{H}_{7} \mathrm{NO}_{6}$

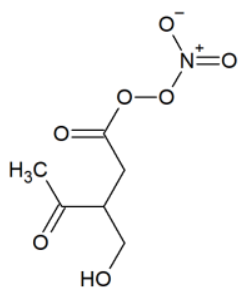

3-(hydroxymethyl)-1-(nitroperoxy) pentane-1,4-dione

Molecular Formula: $\quad \mathrm{C}_{6} \mathrm{H}_{9} \mathrm{NO}_{7}$

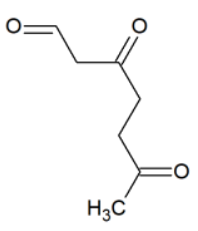

3,6-dioxoheptanal

Molecular Formula: $\quad \mathrm{C}_{7} \mathrm{H}_{10} \mathrm{O}_{3}$ cyclohexyl nitrate

Molecular Formula: $\quad \mathrm{C}_{9} \mathrm{H}_{15} \mathrm{NO}_{5}$ 


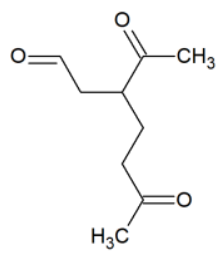

3-acetyl-6-oxoheptanal

Molecular Formula: $\mathrm{C}_{9} \mathrm{H}_{14} \mathrm{O}_{3}$

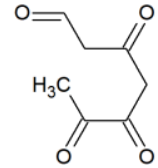

3,5,6-trioxoheptanal

Molecular Formula: $\mathrm{C}_{7} \mathrm{H}_{8} \mathrm{O}_{4}$

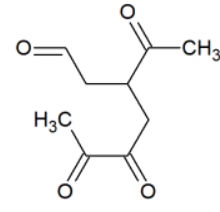

3-acetyl-5,6-dioxoheptanal

Molecular Formula: $\mathrm{C}_{9} \mathrm{H}_{12} \mathrm{O}_{4}$

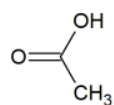

acetic acid

Molecular Formula: $\mathrm{C}_{2} \mathrm{H}_{4} \mathrm{O}_{2}$

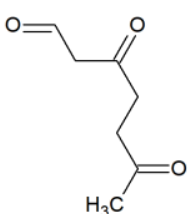

3,6-dioxoheptanal

Molecular Formula: $\mathrm{C}_{7} \mathrm{H}_{10} \mathrm{O}_{3}$

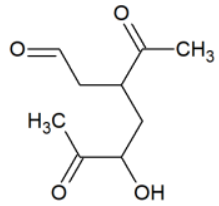

3-acetyl-5-hydroxy-6-oxoheptanal

Molecular Formula: $\mathrm{C}_{9} \mathrm{H}_{14} \mathrm{O}_{4}$

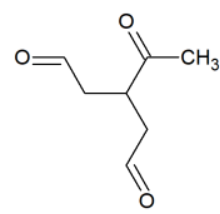

3-acetylpentanedial

Molecular Formula: $\mathrm{C}_{7} \mathrm{H}_{10} \mathrm{O}$

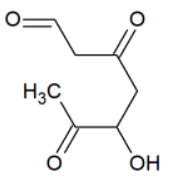

5-hydroxy-3,6-dioxoheptanal

Molecular Formula: $\mathrm{C}_{7} \mathrm{H}_{10} \mathrm{O}_{4}$

Figure S28: Top 10 gas-phase products from limonene dark ozonolysis at the end of the high hydrocarbon (DO_HHC).

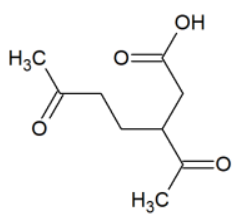

3-acetyl-6-oxoheptanoic acid

Molecular Formula: $\mathrm{C}_{9} \mathrm{H}_{14} \mathrm{O}_{4}$

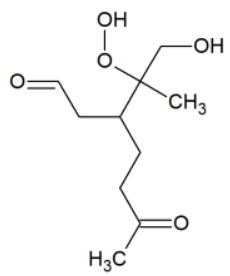

3-(2-hydroperoxy-1-hydroxypropan2-yl)-6-oxoheptanal Molecular Formula: $\mathrm{C}_{10} \mathrm{H}_{18} \mathrm{O}_{5}$

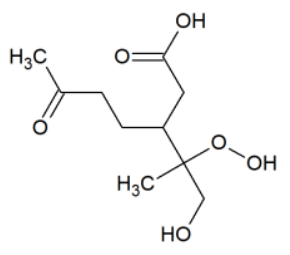

3-(2-hydroperoxy-1-hydroxypropan2-yl)-6-oxoheptanoic acid Molecular Formula: $\mathrm{C}_{10} \mathrm{H}_{18} \mathrm{O}_{6}$

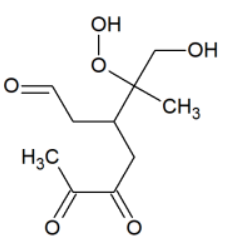

3-(2-hydroperoxy-1-hydroxypropan2-yl)-5,6-dioxoheptanal

Molecular Formula: $\mathrm{C}_{10} \mathrm{H}_{16} \mathrm{O}_{6}$

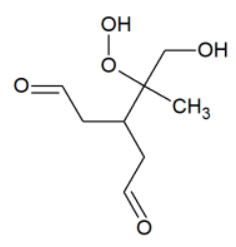

3-(2-hydroperoxy-1-hydroxypropan2-yl)pentanedial

Molecular Formula: $\mathrm{C}_{8} \mathrm{H}_{14} \mathrm{O}_{5}$<smiles>CC(=O)C(O)CC(CC=O)C(C)(CO)OO</smiles>

3-(2-hydroperoxy-1-hydroxypropan2-yl)-5-hydroxy-6-oxoheptanal

Molecular Formula: $\mathrm{C}_{10} \mathrm{H}_{18} \mathrm{O}_{6}$

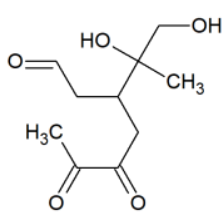

3-(1,2-dihydroxypropan-2-yl)-5, 6-dioxoheptanal

Molecular Formula: $\mathrm{C}_{10} \mathrm{H}_{16} \mathrm{O}_{5}$

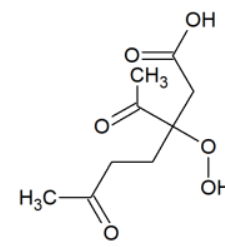

3-acetyl-3-hydroperoxy6-oxoheptanoic acid

Molecular Formula: $\mathrm{C}_{9} \mathrm{H}_{14} \mathrm{O}_{6}$

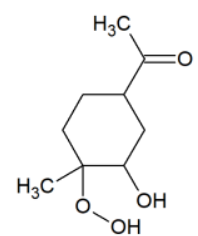

1-(4-hydroperoxy-3-hydroxy-4methylcyclohexyl)ethan-1-one

Molecular Formula: $\mathrm{C}_{9} \mathrm{H}_{16} \mathrm{O}_{4}$

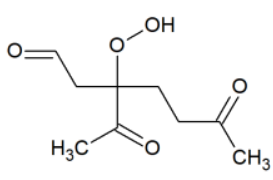

3-acetyl-3-hydroperoxy-6-oxoheptanal Molecular Formula: $\mathrm{C}_{9} \mathrm{H}_{14} \mathrm{O}_{5}$

Figure S29: Top 10 particle-phase products from limonene dark ozonolysis at the end of the high hydrocarbon (DO_HHC). 

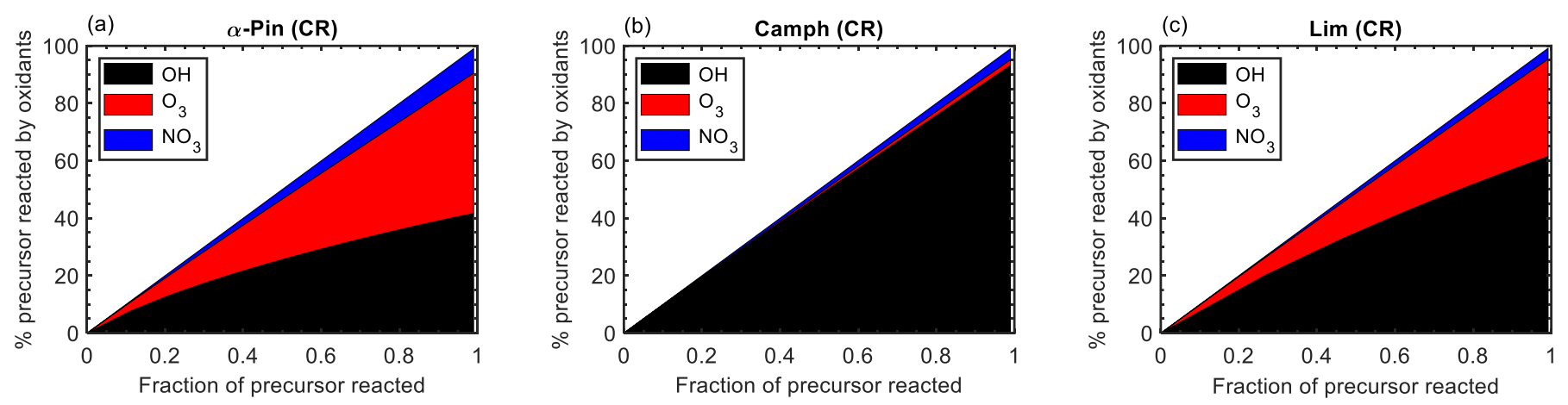

Figure S30: Percentage of precursor reacted by $\mathrm{OH}$ (black), $\mathrm{O}_{3}$ (red), and $\mathrm{NO}_{3}$ (blue) as a function of fraction of precursor reacted for $\alpha$-pinene, camphene, and limonene during controlled reactivity $(\mathrm{CR})$ simulations.

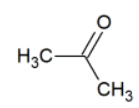

propan-2-one

Molecular Formula: $\mathrm{C}_{3} \mathrm{H}_{6} \mathrm{O}$

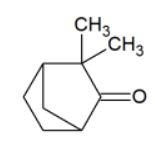

3,3-dimethylbicyclo[2.2.1] heptan-2-one

Molecular Formula: $\mathrm{C}_{9} \mathrm{H}_{14} \mathrm{O}$

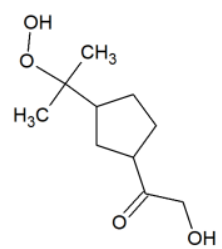

1-[3-(2-hydroperoxypropan-2-yl)cyclo pentyl]-2-hydroxyethan-1-one

Molecular Formula: $\mathrm{C}_{10} \mathrm{H}_{18} \mathrm{O}_{4}$

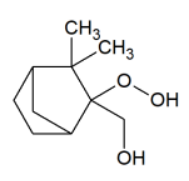

(2-hydroperoxy-3,3-dimethylbicyclo [2.2.1]heptan-2-yl)methanol

Molecular Formula: $\mathrm{C}_{10} \mathrm{H}_{18} \mathrm{O}_{3}$

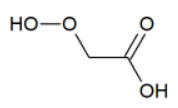

hydroperoxyacetic acid

Molecular Formula: $\mathrm{C}_{2} \mathrm{H}_{4} \mathrm{O}_{4}$

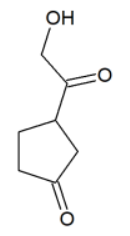

3-(hydroxyacetyl)cyclopentan-1-one Molecular Formula: $\mathrm{C}_{7} \mathrm{H}_{10} \mathrm{O}_{3}$

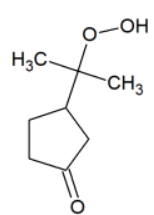

3-(2-hydroperoxypropan-2-yl) cyclopentan-1-one

Molecular Formula: $\mathrm{C}_{8} \mathrm{H}_{14} \mathrm{O}_{3}$

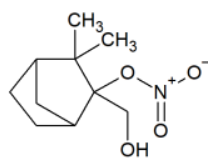

elecular Formula: $\mathrm{C}_{10} \mathrm{H}_{17} \mathrm{NO}_{4}$

\section{.}

Figure S31: Top 10 gas-phase products from camphene at the end of the controlled reactivity simulation. 


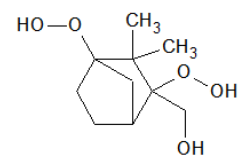

[2,4-bis(hydroperoxy)-3,3-dimethyl bicyclo[2.2.1] heptan-2-yl]methanol

Molecular Formula: $\mathrm{C}_{10} \mathrm{H}_{18} \mathrm{O}_{5}$

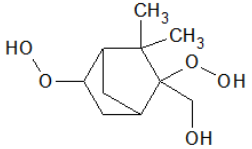

[2,5-bis(hydroperoxy)-3,3-dimethyl bicyclo[2.2.1]heptan-2-yl]methanol

Molecular Formula: $\mathrm{C}_{10} \mathrm{H}_{18} \mathrm{O}_{5}$

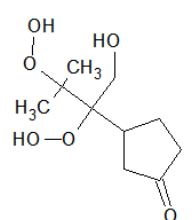

3-[2,3-bis(hydroperoxy)-1-hydroxy-3methylbutan-2-yl]cyclopentan-1-one

Molecular Formula: $\mathrm{C}_{10} \mathrm{H}_{18} \mathrm{O}_{6}$

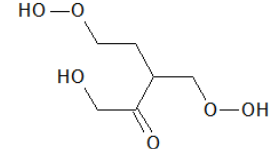

5-hydroperoxy-3-(hydroperoxy methyl)-1-hydroxypentan-2-one

Molecular Formula: $\mathrm{C}_{6} \mathrm{H}_{12} \mathrm{O}_{6}$

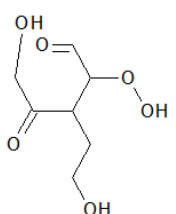

2-hydroperoxy-5-hydroxy-3-(2hydroxyethyl)-4-oxopentanal

Molecular Formula: $\mathrm{C}_{7} \mathrm{H}_{12} \mathrm{O}_{6}$

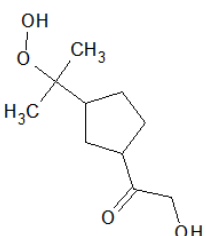

1-[3-(2-hydroperoxypropan-2-yl)cyclo pentyl]-2-hydroxyethan-1-one

Molecular Formula: $\mathrm{C}_{10} \mathrm{H}_{18} \mathrm{O}_{4}$

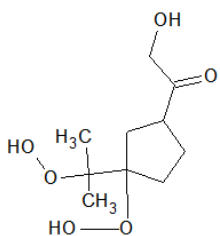

1-[3-hydroperoxy-3-(2-hydroperoxypropan2-yl)cyclopentyl]-2-hydroxyethan-1-one

Molecular Formula: $\mathrm{C}_{10} \mathrm{H}_{18} \mathrm{O}_{6}$

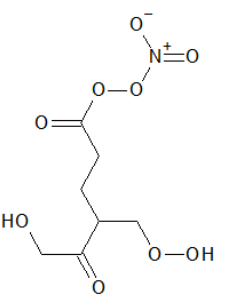

4-hydroperoxy-2-(hydroxymethyl)-3,3-di methylbicyclo[2.2.1]heptan-2-yl nitrate

3-hydroperoxy-1-hydroxy-3-methyl-2 (3-oxocyclopentyl)butan-2-yl nitrate

Molecular Formula: $\mathrm{C}_{10} \mathrm{H}_{17} \mathrm{NO}_{7}$ 4-(hydroperoxymethyl)-6-hydroxy-1(nitroperoxy)hexane-1,5-dione

Molecular Formula: $\mathrm{C}_{7} \mathrm{H}_{11} \mathrm{NO}_{9}$

Figure S32: Top 10 particle-phase products from camphene at the end of the controlled reactivity simulation.
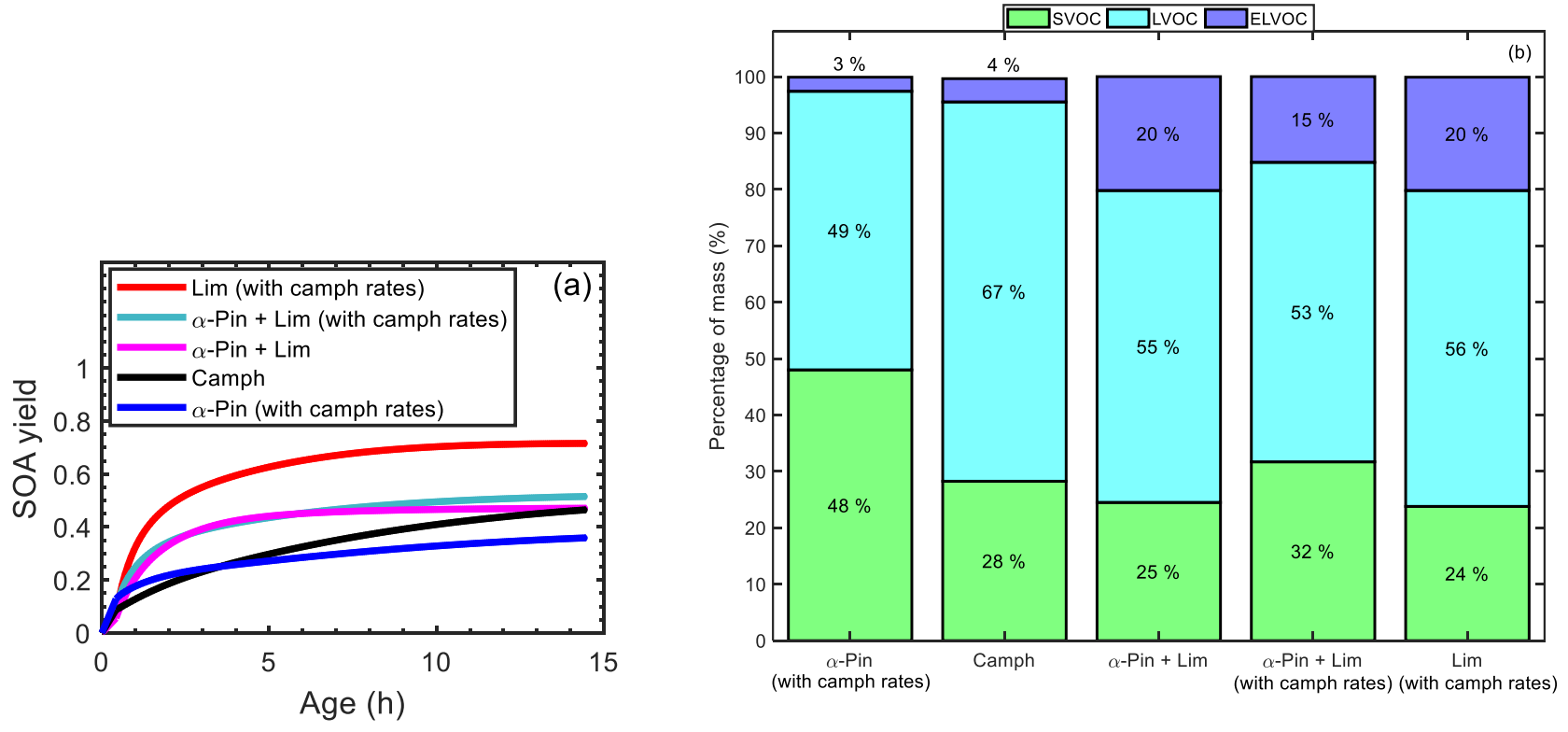

Figure S33: (a) Simulated SOA yield as a function of atmospheric aging time for: camphene (black line), $50 \%$-pinene + $50 \%$ limonene (magenta line), $\alpha$-pinene with camphene rate constants (blue line), limonene with camphene rate constants (red line), and $50 \% \alpha$-pinene $+50 \%$ limonene where the rate constants of $\alpha$-pinene and limonene were replaced with the rate constants of camphene (green line); and (b) mass percentage of particle-phase compounds binned in four volatility categories at the end of the controlled reactivity simulations for: camphene, $50 \% \alpha$-pinene $+50 \%$ limonene, $\alpha$-pinene with camphene rate constants, limonene with camphene rate constants, and $50 \% \alpha$-pinene $+50 \%$ limonene where the rate constants of $\alpha$-pinene and limonene were replaced with the rate constants of camphene. 